Article

\title{
Lipidated Analogs of the LL-37-Derived Peptide Fragment KR12-Structural Analysis, Surface-Active Properties and Antimicrobial Activity
}

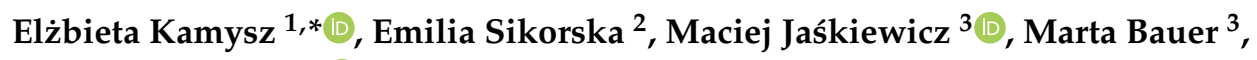 \\ Damian Neubauer $^{3}{ }^{\oplus}$, Sylwia Bartoszewska ${ }^{3}$, Wioletta Barańska-Rybak ${ }^{4}$ and Wojciech Kamysz ${ }^{3}$ \\ 1 Laboratory of Chemistry of Biological Macromolecules, Department of Molecular Biotechnology, Faculty of \\ Chemistry, University of Gdańsk, 80-308 Gdańsk, Poland \\ 2 Laboratory of Structural Studies of Biopolymers, Department of Organic Chemistry, Faculty of Chemistry, \\ University of Gdańsk, 80-308 Gdańsk, Poland; emilia.sikorska@ug.edu.pl \\ 3 Department of Inorganic Chemistry, Faculty of Pharmacy, Medical University of Gdańsk, 80-416 Gdańsk, \\ Poland; mj@gumed.edu.pl (M.J.); marta.bauer@gumed.edu.pl (M.B.); \\ damian.neubauer@gumed.edu.pl (D.N.); sylwia.bartoszewska@gumed.edu.pl (S.B.); \\ wojciech.kamysz@gumed.edu.pl (W.K.) \\ 4 Department of Dermatology, Venereology and Allergology, Faculty of Medicine, Medical University of \\ Gdańsk, 80-214 Gdańsk, Poland; wioletta.baranska-rybak@gumed.edu.pl \\ * Correspondence: elzbieta.kamysz@ug.edu.pl; Tel.: +48-58-523-5011
}

Received: 21 December 2019; Accepted: 28 January 2020; Published: 30 January 2020

\begin{abstract}
An increasing number of multidrug-resistant pathogens is a serious problem of modern medicine and new antibiotics are highly demanded. In this study, different n-alkyl acids $\left(\mathrm{C}_{2}-\mathrm{C}_{14}\right)$ and aromatic acids (benzoic and trans-cinnamic) were conjugated to the $\mathrm{N}$-terminus of KR12 amide. The effect of this modification on antimicrobial activity (ESKAPE bacteria and biofilm of Staphylococcus aureus) and cytotoxicity (human red blood cells and HaCaT cell line) was examined. The effect of lipophilic modifications on helicity was studied by CD spectroscopy, whereas peptide self-assembly was studied by surface tension measurements and NMR spectroscopy. As shown, conjugation of the KR12- $\mathrm{NH}_{2}$ peptide with $\mathrm{C}_{4}-\mathrm{C}_{14}$ fatty acid chains enhanced the antimicrobial activity with an optimum demonstrated by $\mathrm{C}_{8}-\mathrm{KR} 12-\mathrm{NH}_{2}$ (MIC $1-4 \mu \mathrm{g} / \mathrm{mL}$ against ESKAPE strains; MBEC of S. aureus $4-16 \mu \mathrm{g} / \mathrm{mL}$ ). Correlation between antimicrobial activity and self-assembly behavior of $\mathrm{C}_{14}-\mathrm{KR} 12-\mathrm{NH}_{2}$ and $\mathrm{C}_{8}-\mathrm{KR} 12-\mathrm{NH}_{2}$ has shown that the former self-assembled into larger aggregated structures, which reduced its antimicrobial activity. In conclusion, $\mathrm{N}$-terminal modification can enhance antimicrobial activity of $\mathrm{KR} 12-\mathrm{NH}_{2}$; however, at the same time, the cytotoxicity increases. It seems that the selectivity against pathogens over human cells can be achieved through conjugation of peptide $N$-terminus with appropriate n-alkyl fatty and aromatic acids.
\end{abstract}

Keywords: ESKAPE pathogens; Staphylococcus aureus; KR12; LL-37; lipopeptide; critical aggregation concentration; CD spectroscopy; NMR; biofilm; cytotoxicity

\section{Introduction}

The occurrence of multidrug-resistant (MDR) bacterial strains faces many difficulties in the therapy of some infections due to prolonged treatment and frequent relapses. An increasing number of MDR pathogens is mainly associated with persistent and abused use of antibiotics and just those strains are mostly associated with hospital flora. The ESKAPE pathogens (Enterococcus faecium, Staphylococcus aureus, Klebsiella pneumoniae, Acinetobacter baumannii, Pseudomonas aeruginosa and Enterobacter spp.) are bacterial species responsible for most of nosocomial infections [1]. Moreover, recent epidemiological data have shown that the therapy of infections caused by those bacteria is also associated with 
the highest risk of mortality [2]. According to the latest reports of World Health Organization (WHO), all of the ESKAPE pathogens are listed in the group of bacteria for which new antibiotics are highly demanded [3]. It should be noted that one of the species in the high priority group are methicillin-resistant $S$. aureus (MRSA), which are prevalent species in environment making them the major source of hospital-acquired infections (HAIs) [4]. It has been estimated that almost $44 \%$ of all HAIs are caused by those bacteria, with indication of being responsible for over $20 \%$ of excessive mortality $[5,6]$. The therapy of infections caused by MRSA is even more challenging as these strains produce a number of mechanisms allowing them to invade into the organisms, including avoidance of opsonization by antibodies and complement system, disruption of chemotaxis and lysis of neutrophils. Because of their ability to survive inside leukocytes, the infections tend to move into a chronic stage and recur after recovering. Furthermore, the therapy often needs prolonged hospitalization and commonly tends to be ineffective. An additional complication of the therapy is the ability of bacteria to form biofilms - an organized three-dimensional structure characterized by enhanced resistance to antibiotics [7]. It has been estimated that approximately $80 \%$ of chronic and recurrent infections are associated with the biofilm occurrence [8]. Low effectiveness of the current approaches to the therapy of HAIs together with accompanying side-effects adversely affect the patient's health. A multitude of antibiotics often fail to be effective in the treatment because of MDR strains. Therapeutic difficulties accompanying the majority of infections escalates the need to search for new effective drugs. Antimicrobial peptides (AMPs) are a promising class of antimicrobial compounds which have a chance to fight resistant pathogens owing to their rapid membrane-targeting bactericidal mode of action and the predicted low propensity for development of resistance [9-11]. One of the AMPs is a linear, cationic, $\alpha$-helical and amphipathic peptide LL-37 (LLGDFFRKSKEKIGKEFKRIVQRIKDFLRNLVPRTES), the member of the human cathelicidin family [12-14]. This peptide is released from its precursor, hCAP-18, through proteolytic processing by proteinase 3, a serine proteinase secreted from neutrophils [14]. Interestingly, the hCAP-18 found in seminal plasma can also be hydrolyzed by vaginal gastricsin. As a result, instead of LL-37 another peptide (ALL-38) can be generated. Although this compound contains additional alanine at the $\mathrm{N}$-terminus, exhibits comparable antimicrobial activity [15]. Furthermore, LL-37 is found in variety of cells, tissues and body fluids such as leukocytes, bone marrow, milk, salivary glands, skin, respiratory tract, epithelium cells and leukocytes within the digestive tract, urinary tract as well as squamous epithelium of the mouth and tongue $[12,13,16,17]$. This compound exhibits a broad spectrum of antibacterial activity against both planktonic cells and biofilms of Gram-positive and Gram-negative bacteria, which promotes it as a candidate for a new antibiotic [18,19]. However, LL-37 is a relatively long peptide, which makes it to be expensive for manufacturing. Thus, the search for a novel, shorter analogs of LL-37 is desired. Some fragments of LL-37 have been evaluated to identify improved antimicrobial derivatives (for instance KR12, FK-13, GF17, 17BIPHE2) [20-24]. Both LL-37 and its shorter active analogs adopt a helical structure in the presence of membrane lipids [23-25]. The shortest $\alpha$-helical fragment of LL-37 with documented antimicrobial activity is KR12 amide (KRIVQRIKDFLR-NH ${ }_{2}$ ) $[20,21,26]$. This peptide, a truncated form of LL-37, shares two common features of antimicrobial peptides: a positive net charge and an amphipathic structure, which determine their antimicrobial activity.

In this article, we report the synthesis of a series of lipopeptides derivatized with variable length fatty acids or aromatic acids covalently attached to the $\mathrm{N}$-terminus of $\mathrm{KR} 12-\mathrm{NH}_{2}$, and their antimicrobial activity against planktonic cells of ESKAPE bacteria. The fatty acid tail was introduced to $\mathrm{KR} 12-\mathrm{NH}_{2}$, because in the literature it was found that addition a fatty acid residue to AMPs may improve effectiveness of peptides as antimicrobial agents by enhancing their ability to form either secondary structures or oligomerize upon interacting with bacterial membranes [27-29]. We also demonstrate the activity of the tested peptides against biofilm formed by reference strains of $S$. aureus (including MRSA), because one of the obstacles complicating therapy of staphylococcal infections is the growth of biofilm. Relationships between antimicrobial activity and hemolytic activity as well as cytotoxicity of the peptides were also determined. The effect of $\mathrm{N}$-terminal modifications on helicity of the $\mathrm{KR} 12-\mathrm{NH}_{2}$ peptide was studied by 
CD spectroscopy. The ability of the selected lipopeptides to spontaneous self-assembly in solution was evaluated with surface tension measurements and NMR spectroscopy.

\section{Results and Discussion}

This section describes and discusses results MS and RP-HPLC analyses of peptides (2.1), evaluation of their antimicrobial activity against planktonic $S$. aureus and ESKAPE strains and biofilm of $S$. aureus reference strains (2.2), as well as studies on hemolysis (2.3) and cytotoxicity (2.4). Moreover, CD spectroscopy (2.5), critical aggregation concentration (CAC) and NMR spectroscopy (2.6) were included to learn how $N$-terminal modification affects secondary-structure and peptide self-assembly. As found, the activity of the studied peptides was determined by many concurrent parameters, including hydrophobicity, conformation or tendency to self-assembly.

\subsection{Peptide Synthesis and Purification}

Peptides I-X were synthesized by solid-phase method using Fmoc chemistry. Their purity was higher than $95 \%$ as shown by analytical reversed-phase high-performance liquid chromatography (RP-HPLC). The electrospray ionization mass spectrometry (ESI MS) in positive ion mode confirmed identity of the purified peptides. Physicochemical characteristics of the peptides are shown in Table 1.

Table 1. Characteristics of the peptides.

\begin{tabular}{|c|c|c|c|c|c|c|c|}
\hline \multirow{2}{*}{ Peptide } & \multirow{2}{*}{ Name } & \multirow{2}{*}{$\begin{array}{l}\text { Net } \\
\text { Charge }\end{array}$} & \multirow{2}{*}{$\begin{array}{l}\text { HPLC } t^{\prime} R \\
\quad(\min )\end{array}$} & \multirow{2}{*}{$\begin{array}{l}\text { Average Mass } \\
\text { (Da) }\end{array}$} & \multicolumn{3}{|c|}{ MS Analysis } \\
\hline & & & & & $z$ & $m / z$ calc. & $m / z$ found \\
\hline \multirow{3}{*}{ I } & \multirow{3}{*}{$\begin{array}{l}\text { Ac-KR12-NH }{ }_{2} \\
\left(\mathrm{C}_{2}-\mathrm{KR} 12-\mathrm{NH}_{2}\right)\end{array}$} & \multirow{3}{*}{+4} & \multirow{3}{*}{3.58} & \multirow{3}{*}{1612.96} & 2 & 807.49 & 807.29 \\
\hline & & & & & 3 & 538.66 & 538.69 \\
\hline & & & & & 4 & 404.25 & 404.47 \\
\hline \multirow{3}{*}{ II } & \multirow{3}{*}{$\mathrm{C}_{4}-\mathrm{KR} 12-\mathrm{NH}_{2}$} & \multirow{3}{*}{+4} & \multirow{3}{*}{3.99} & \multirow{3}{*}{1641.02} & 2 & 821.52 & 821.38 \\
\hline & & & & & 3 & 548.01 & 547.73 \\
\hline & & & & & 4 & 411.26 & 411.36 \\
\hline \multirow{3}{*}{ III } & \multirow{3}{*}{$\mathrm{C}_{6}-\mathrm{KR} 12-\mathrm{NH}_{2}$} & \multirow{3}{*}{+4} & \multirow{3}{*}{4.42} & \multirow{3}{*}{1669.07} & 2 & 835.54 & 835.16 \\
\hline & & & & & 3 & 557.36 & 556.84 \\
\hline & & & & & 4 & 418.28 & 418.35 \\
\hline \multirow{4}{*}{ IV } & \multirow{4}{*}{$\mathrm{C}_{8}-\mathrm{KR} 12-\mathrm{NH}_{2}$} & \multirow{4}{*}{+4} & \multirow{4}{*}{4.88} & \multirow{4}{*}{1697.12} & 2 & 849.57 & 849.46 \\
\hline & & & & & 3 & 566.71 & 566.65 \\
\hline & & & & & 4 & 425.29 & 425.31 \\
\hline & & & & & 5 & 340.43 & 340.56 \\
\hline \multirow{3}{*}{$\mathrm{V}$} & \multirow{3}{*}{$\mathrm{C}_{10}-\mathrm{KR} 12-\mathrm{NH}_{2}$} & & & & 2 & 863.60 & 863.43 \\
\hline & & +4 & 5.38 & 1725.18 & 3 & 576.07 & 575.86 \\
\hline & & & & & 4 & 432.30 & 432.20 \\
\hline & & & & & 2 & 877.62 & 877.03 \\
\hline VI & $\mathrm{C}_{12}-\mathrm{KR} 12-\mathrm{NH}_{2}$ & +4 & 5.86 & 1753.23 & 3 & 585.42 & 585.04 \\
\hline & & & & & 4 & 439.32 & 439.18 \\
\hline & & & & & 2 & 891.65 & 891.42 \\
\hline VII & $\mathrm{C}_{14}-\mathrm{KR} 12-\mathrm{NH}_{2}$ & +4 & 6.39 & 1781.28 & 3 & 594.77 & 594.59 \\
\hline & & & & & 4 & 446.33 & 446.04 \\
\hline & & & & & 2 & 838.52 & 838.14 \\
\hline VIII & $\begin{array}{l}\text { Benzoic } \\
\end{array}$ & +4 & 4.23 & 1675.03 & 3 & 559.35 & 559.00 \\
\hline & & & & & 4 & 419.77 & 419.76 \\
\hline & & & & & 2 & 851.54 & 851.34 \\
\hline IX & trans-Cinnamic & +4 & 4.44 & 1701.07 & 3 & 568.03 & 567.58 \\
\hline & acid-KRIZ- $\mathrm{NH}_{2}$ & & & & 4 & 426.28 & 425.85 \\
\hline & & & & & 2 & 786.47 & 786.23 \\
\hline & $\mathrm{KR} 12-\mathrm{NH}_{2}$ & & & & 3 & 524.65 & 524.69 \\
\hline$X$ & $\left(\right.$ KRIVQRIKDFLR-NH ${ }_{2}$ ) & +5 & 2.68 & 1570.93 & 4 & 393.74 & 393.94 \\
\hline & & & & & 5 & 315.19 & 315.18 \\
\hline
\end{tabular}

$z$-ion charge, $m / z$ - mass to charge ratio; adjusted retention time $\left(t_{R}^{\prime}\right)$ is an analyte's retention time $\left(t_{R}\right)$ minus the elution time of an unretained peak $\left(t_{\mathrm{m}}\right)$. 
Conjugation of KR12- $\mathrm{NH}_{2} \mathrm{~N}$-terminal amino group with aliphatic or aromatic acids result in compounds with a reduced net charge $(+4$ vs. +5$)$ and enhanced hydrophobicity, as shown by RP-HPLC. Results of this evaluation are presented in Table 1. Moreover, the number of carbon atoms in the $N$-terminal acid was plotted against the adjusted retention time (Figure 1).

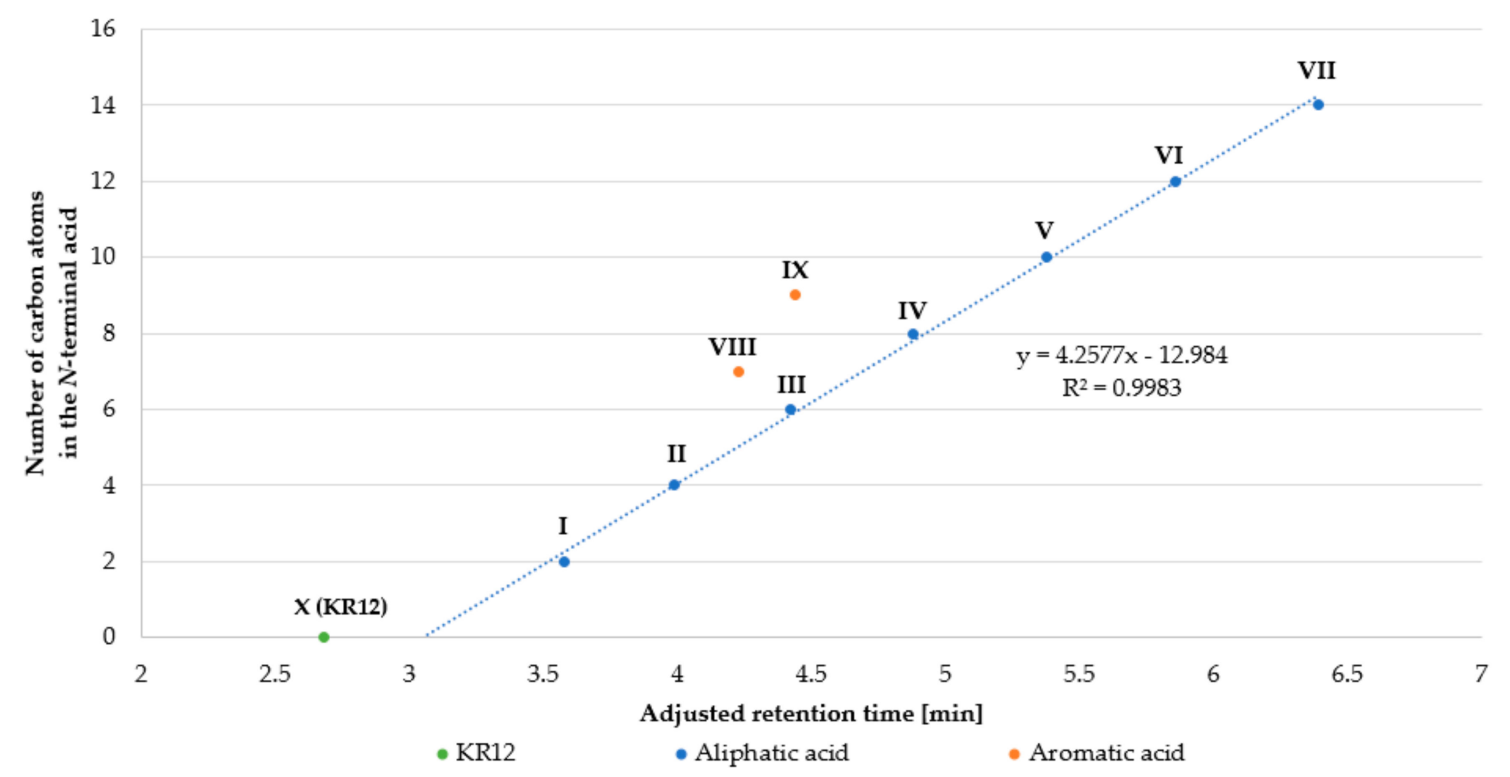

Figure 1. The number of carbon atoms in the $N$-terminal acid residue versus adjusted retention time.

Peptides with $N$-terminal aliphatic acid to generate a homologous series differ in the number of carbon atoms (methylene groups). It can be seen that retention time (hydrophobicity) of peptides I-VII increased proportionally to the number of carbon atoms (linear regression, $R^{2}=0.9983$ ). Retention time of $\mathrm{KR} 12-\mathrm{NH}_{2}(+5)$ is shifted to lower values than those predicted using regression equation of I-VII (calculated 3.05 vs. measured $2.68 \mathrm{~min}$ ), mainly due to its higher net charge (+5). Analogs with an aromatic acid at the $\mathrm{N}$-terminus did not follow this trend. The calculated retention times of analogs with identical number of carbon atoms in aliphatic acids as compared to those with aromatic VIII $\left(\mathrm{C}_{7}\right)$ and IX $\left(\mathrm{C}_{9}\right)$ acids were distinctly higher (more hydrophobic) than the experimentally determined ones (VIII: 4.23 vs. 4.69 min calc.; IX: 4.44 vs. 5.16 min calc.). This phenomenon is the result of different carbon hybridization. In aromatic acids, carbon atoms are $\mathrm{sp}^{2}$ hybridized and in the aliphatic ones they are $\mathrm{sp}^{3}$ hybridized (excluding carbon atom of carboxylic group), which influences polarity, shape and planarity (aromatic ring) of aromatic compounds, and both can affect retention time [30-32].

\subsection{Antimicrobial Assay}

In our preliminary research, we tested LL-37 and KR12- $\mathrm{NH}_{2}(\mathbf{X})$ against a reference strain of S. aureus ATCC 25923. Minimal inhibitory concentrations (MICs) of S. aureus strain were $256 \mu \mathrm{g} / \mathrm{mL}$ for peptide KR12- $\mathrm{NH}_{2}$ and $>512 \mu \mathrm{g} / \mathrm{mL}$ for LL-37 in analysis performed in the Mueller-Hinton medium. MICs for S. aureus strain cultivated in $1 \%$ Bacto Peptone medium were $64 \mu \mathrm{g} / \mathrm{mL}$ for peptide KR12- $\mathrm{NH}_{2}$ and $>512$ for LL-37. We also tested antimicrobial activity of LL-37 and KR12-NH $\mathrm{N}_{2}$ against clinical strains of $S$. aureus acquired from the skin and nose and it strongly depended on the bacterial strains of S. aureus (MICs values ranged between 1 and $>512 \mu \mathrm{g} / \mathrm{mL}$ ) [33]. Because antistaphylococcal activities of KR12- $\mathrm{NH}_{2}$ and LL-37 were comparable, we decided to introduce a lipophilic residue to peptide KR12- $\mathrm{NH}_{2}(\mathbf{X})$. Peptide $\mathbf{X}$ and its nine analogs (I-IX) were tested against selected reference strains of ESKAPE bacteria (Table 2-E. faecium, K. pneumoniae, A. baumannii, P. aeruginosa, K. aerogenes; Table 3-several reference strains of S. aureus including MRSA ATCC 33591) and staphylococcal biofilm (Table 4). The antimicrobial activity of the synthesized peptides was dependent on the number of carbon atoms in the $\mathrm{N}$-acyl substituent. A high activity against planktonic forms of the bacteria and 
the staphylococcal biofilm was found for peptides III-V and IX (Tables 2-4). The most effective was the analog of KR12- $\mathrm{NH}_{2}$ modified in the $N$-terminal part of the molecule with octanoic acid residue $\left(\mathrm{C}_{8}-\mathrm{KR} 12-\mathrm{NH}_{2}\right.$, peptide IV) for which the minimal inhibitory concentration (MIC) values ranged between 1 and $4 \mu \mathrm{g} / \mathrm{mL}$ (Tables 2 and 3), while the minimal biofilm eradication concentrations (MBECs) of $S$. aureus strains were four-fold higher than the MIC values and ranged between 4 and $16 \mu \mathrm{g} / \mathrm{mL}$. Generally, the conjugation of the KR12- $\mathrm{NH}_{2}$ with both longer and shorter hydrocarbon acyl chains than that of $C_{8}$ resulted in a decrease in antimicrobial activity. The next active compound was analog KR12-NH $\mathrm{NH}_{2}$ modified with trans-cinnamic acid residue (peptide IX). For this particular compound, the MIC values ranged between 1 and $8 \mu \mathrm{g} / \mathrm{mL}$ (Tables 2 and 3). The MBEC values were four-fold higher than those of MIC values and ranged between 4 and $32 \mu \mathrm{g} / \mathrm{mL}$. As a rule, modification of the KR12 amide with fatty acid residues $\left(C_{4}-C_{14}\right)$ intensified antimicrobial potency against the tested bacteria. An exception was found only for analog modified with $\mathrm{C}_{4}$ (II), which was inactive against A. baumannii. In general, antimicrobial activity of the analogs depended on their hydrophobicity (N-terminal acid). The relation between antimicrobial activity of the peptides against Gram-positive (S. aureus ATCC 25923) and Gram-negative (P. aeruginosa ATCC 9027) strains and their hydrophobicity (adjusted retention time) is presented on the Figure 2.

Table 2. The minimal inhibitory concentration (MIC) values $(\mu \mathrm{g} / \mathrm{mL})$ of the peptides against reference strains of ESKAPE pathogens.

\begin{tabular}{cccccc}
\hline Peptide & $\begin{array}{c}\text { E. faecium } \\
\text { ATCC 700221 }\end{array}$ & $\begin{array}{c}\text { K. pneumoniae } \\
\text { ATCC 700603 }\end{array}$ & $\begin{array}{c}\text { A. baumannii } \\
\text { ATCC BAA-1605 }\end{array}$ & $\begin{array}{c}\text { P. aeruginosa } \\
\text { ATCC 9027 }\end{array}$ & $\begin{array}{c}\text { K. aerogenes } \\
\text { ATCC 13048 }\end{array}$ \\
\hline I & 16 & $>256$ & $>256$ & 64 & $>256$ \\
II & 4 & 128 & $>256$ & 32 & 128 \\
III & 2 & 16 & 16 & 8 & 16 \\
IV & 1 & 2 & 2 & 2 & 2 \\
V & 2 & 16 & 8 & 8 & 16 \\
VI & 4 & 32 & 16 & 32 & 32 \\
VII & 8 & 64 & 32 & 128 & 128 \\
VIII & 1 & 16 & 16 & 8 & 4 \\
IX & 1 & 4 & 4 & 4 & $>256$ \\
X & 8 & $>256$ & 256 & 16 & \\
\hline
\end{tabular}

Table 3. The MIC values ( $\mu \mathrm{g} / \mathrm{mL}$ ) of the test peptides against reference strains of S. aureus.

\begin{tabular}{cccccc}
\hline Peptide & $\begin{array}{c}\text { S. aureus } \\
\text { ATCC } 25923\end{array}$ & $\begin{array}{c}\text { S. aureus } \\
\text { ATCC } \mathbf{6 5 3 8}\end{array}$ & $\begin{array}{c}\text { S. aureus } \\
\text { ATCC 33591 }\end{array}$ & $\begin{array}{c}\text { S. aureus } \\
\text { ATCC 9144 }\end{array}$ & $\begin{array}{c}\text { S. aureus } \\
\text { ATCC 12598 }\end{array}$ \\
\hline I & $>256$ & 256 & $>256$ & $>256$ & $>256$ \\
II & 128 & 32 & 128 & 64 & 64 \\
III & 16 & 4 & 16 & 8 & 8 \\
IV & 2 & 2 & 2 & 2 & 4 \\
V & 4 & 4 & 4 & 4 & 4 \\
VI & 32 & 32 & 16 & 32 & 32 \\
VII & 128 & 64 & 16 & 64 & 128 \\
VIII & 32 & 8 & 32 & 16 & 4 \\
IX & 8 & 2 & 4 & 4 & $>256$ \\
X & $>256$ & 256 & $>256$ & $>256$ & \\
\hline
\end{tabular}


Table 4. The MBEC values ( $\mu \mathrm{g} / \mathrm{mL})$ of the test peptides against reference strains of S. aureus.

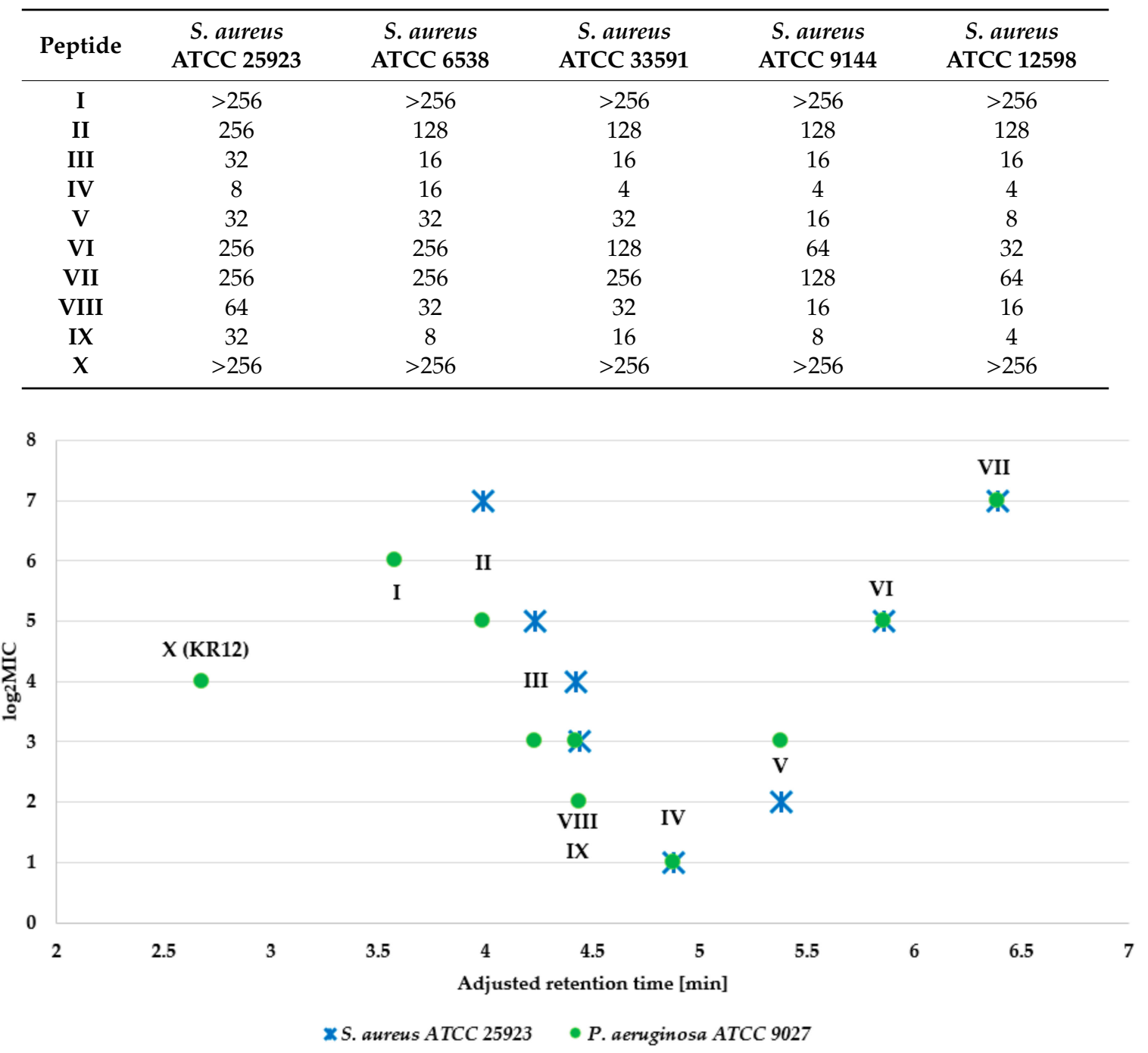

Figure 2. Antimicrobial activity of KR12 amide and its analogs $\left(\log _{2}\right.$ MIC) against S. aureus ATCC 25923 and P. aeruginosa ATCC 9027 versus adjusted retention time.

Positive charge of the peptide is essential for its antimicrobial activity due to interactions with negatively charged pathogen cells. A gradual reduction of positive charge usually results in decrease or loss of antimicrobial activity [34,35]. However, as observed, there was no simple correlation between charge and activity. In case of the studied analogs the $N$-terminal modification reduced net charge from +5 to +4 . Despite the reduction of total positive charge, most of the analogs displayed improved antimicrobial activity when compared to $\mathrm{KR} 12-\mathrm{NH}_{2}$. This finding emphasizes that $\mathrm{N}$-terminal modification also modifies other structural parameters of the peptide that are crucial for activity. The antimicrobial activity of lipopeptides depended on the length of the acyl substituent, which is compatible with earlier reports [27,36,37]. However, in the literature, different fatty acids have been suggested as the optimum modification to provide enhanced antimicrobial activity. For instance, Laverty et al. conjugated a tetrapeptide amide $\mathrm{H}$-Orn-Orn-Trp-Trp- $\mathrm{NH}_{2}$ with saturated fatty acids $\left(\mathrm{C}_{6}-\mathrm{C}_{16}\right)$ and demonstrated that $\mathrm{N}$-acyl substituents of 12-14 carbon atoms in length exhibited the strongest antimicrobial and antibiofilm activities [36]. As a result, the hydrophobicity of the $N$-acyl substituent was pointed as a key determinant of antimicrobial activity for the peptides [36]. Albada et al. also studied the influence of lipidation $\left(\mathrm{C}_{2}-\mathrm{C}_{14}\right)$ on antimicrobial potency of short active unnatural AMPs. In this case, the highest activities against a broad spectrum of pathogens were found for compounds modified with $\mathrm{C}_{8}$ and $\mathrm{C}_{10}$ residues. The authors suggested that the lowered activity of 
peptides lipidated with $\mathrm{C}_{12}$ and $\mathrm{C}_{14}$ could be associated with their poor solubility in media used for microbiological assays [37]. In our study, the optimum modification was found for lipidation with octanoic acid $\left(\mathrm{C}_{8}\right)$.

\subsection{Hemolysis Assay}

The hemolytic activity of peptides I-X was assessed for human red blood cells (hRBCs) to verify their toxicity (Figure 3 and Table 5). Our results indicate that hemolysis of the erythrocytes depended on the number of carbon atoms of the conjugated acid. For longer hydrocarbon acyl chains $\left(C_{2}\right.$ to $\left.C_{14}\right)$, the hemolytic activity increased. For instance, for peptides $\mathbf{I}\left(\mathrm{C}_{2}\right.$ - ethanoic acid) and II $\left(\mathrm{C}_{4}\right.$-butyric acid) the hemolysis of hRBCs was not detected within the studied concentration range $(0.5-256 \mu \mathrm{g} / \mathrm{mL})$. Analogs III and IV (with hexanoic acid $-\mathrm{C}_{6}$ and octanoic acid $-\mathrm{C}_{8}$ ) exhibited a higher hemolytic activity, but it was still below their MIC and MBEC values. The most effective compound against both planktonic cells and the biofilm of $S$. aureus was peptide IV, which caused $5 \%$ hemolysis of $\mathrm{hRBCs}$ at a concentration of $64 \mu \mathrm{g} / \mathrm{mL}$. Peptide IV had a high selectivity index amounting to almost 28 (Table 5). In the case of peptides, V-VII containing hydrocarbon acyl chains from $C_{10}$ to $C_{14}$ the hemolytic activity was comparable and exceeded the values of MIC and MBEC. For these compounds, hemoglobin release was found, beginning from 2-4 $\mu \mathrm{g} / \mathrm{mL}$. Lysis of hRBCs for those peptides was noticed in the range of $64-128 \mu \mathrm{g} / \mathrm{mL}$. As a result, an analog with a tetradecanoic acid (VII) turned out to be the most toxic one. Noteworthy is the fact that conjugation of $\mathrm{KR} 12-\mathrm{NH}_{2}$ with aromatic carboxylic acids, such as benzoic $\left(\mathrm{C}_{7}\right)$ and trans-cinnamic $\left(\mathrm{C}_{9}\right)$ acids led to analogs VIII and IX that were less hemolytic than analogs III $\left(\mathrm{C}_{6}\right)$ and IV $\left(\mathrm{C}_{8}\right)$. However, selectivity index of peptide IX was lower than that of peptide IV (Table 5). Peptide VIII did not cause hemolysis of hRBCs ( $>5 \%$ ) over the whole concentration range. SI value for this peptide was not calculated because minimal hemolytic concentration (MHC) exceeded $256 \mu \mathrm{g} / \mathrm{mL}$. It should be emphasized that peptide $\mathrm{KR} 12-\mathrm{NH}_{2}(\mathbf{X})$, which was used as a base for all modifications, did not cause any significant hemolysis ( $>5 \%)$ over the whole concentration range $(0.5-256 \mu \mathrm{g} / \mathrm{mL})$.

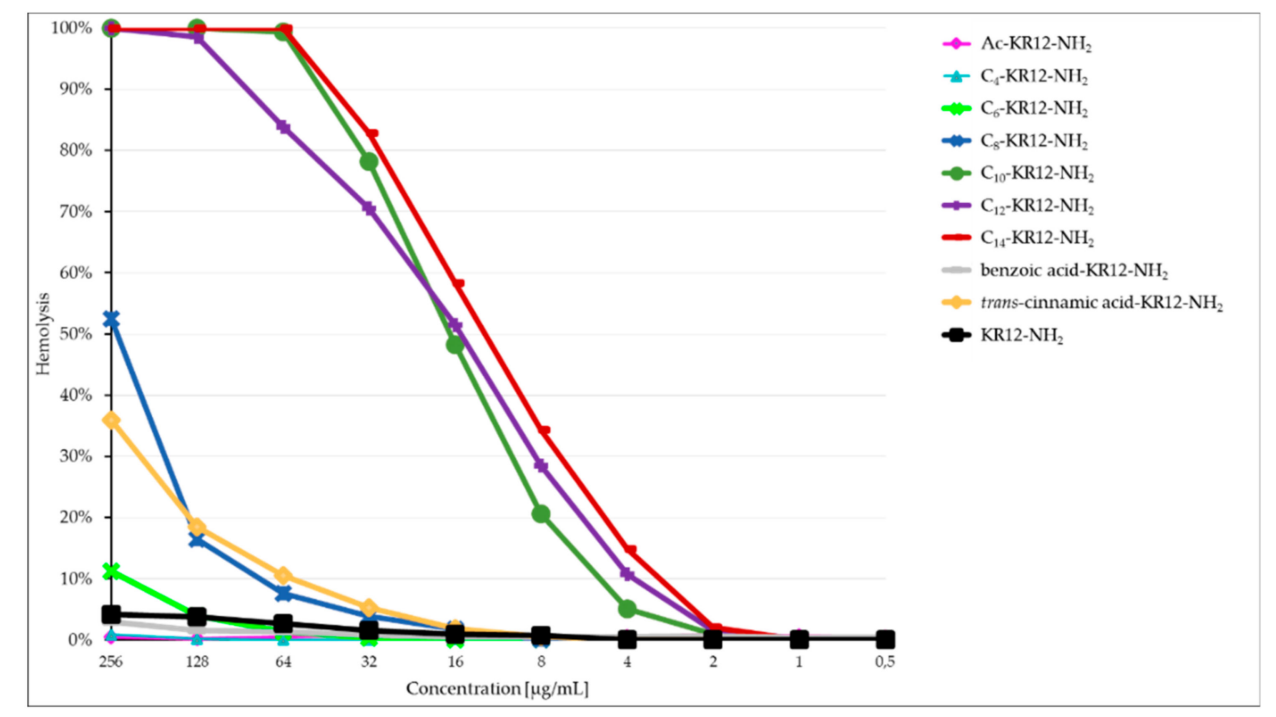

Figure 3. Percentage of hemolysis of erythrocytes versus peptide concentration.

\subsection{MTT Assay}

All the tested peptides exhibited cytotoxicity against human keratinocytes cell line (HaCaT). A 65-fold difference in half maximal inhibitory concentration $\left(\mathrm{IC}_{50}\right)$ values was observed between peptides displaying the highest and lowest degrees of cytotoxicity (Table 5). Only for peptides III-V, VIII and IX, the IC $\mathrm{C}_{50}$ values were higher than the mean MIC ones (GM) for $S$. aureus. Moreover, the highest toxicity was found for peptide VII $\left(\mathrm{C}_{14}\right)$, but its activity against $S$. aureus was relatively poor. On the 
other hand, the least toxic was peptide I. Therefore, for this compound the antimicrobial activity was determined only against E. faecium and P. aeruginosa (16 and $64 \mu \mathrm{g} / \mathrm{mL}$, respectively). Selectivity indices $\mathrm{IC}_{50} / \mathrm{GM}$ against reference strains of $S$. aureus were low. The most selective were analogs modified with aromatic acid residues VIII $\left(C_{7}\right)$ and IX $\left(C_{9}\right)$ with selectivity indices of 2.20 and 2.50, respectively. Several articles on the safety-profile of KR-12 analogs have already been published, indicating high antimicrobial activity and low cytotoxicity of the aforementioned analogs. For instance, in the study of Jacob et al. a series of KR12 analogs were designed and synthesized in order to optimize the $\alpha$-helical structure (KR12-a1 to a7) [21]. As a result, all of the analogs showed insignificant cytotoxicity against macrophages of RAW264.7 cell line and anti-inflammatory activity. Moreover, on the basis of these results, Kim et al. conducted a research on D-amino acid substituted analogs of KR-12-a5 (KRIVKLILKWLR-NH ${ }_{2}$ ) which appeared to be non-toxic against macrophages (RAW264.7) and fibroblasts (NIH-3T3) at whole concentration range [38]. It is worth noticing that Rajasekaran et al. conducted research on alanine scan of FK-13 peptide (FKRIVQRIKDFLR-NH ${ }_{2}$ ), which is also considered to be an antimicrobial region of LL-37 [22]. In this study, the cytotoxicity was determined against both RAW264.7 and HaCaT cell lines. As a result, for majority of peptides the viability of test cells at MIC concentrations were not significantly affected. Furthermore, in the last two cases, the cell selectivity (therapeutic index) was determined in the relation to hemolysis. Respectively, in the study of Kim et al. the most selective was compound with 6-DL, with selectivity of 61.2, while in the article of Rajasekaran et al. the most selective was FK13-a4 with a selectivity equal to 138.4 [22,38]. However, the obtained results should not be compared as in one assay the MHC that caused $10 \%$ of hemolysis was taken into calculation while in another considered concentration was HC50 (50\% hemolysis).

Table 5. MHC, $\mathrm{IC}_{50}, \mathrm{GM}$ and selectivity indices (SI) of peptides determined for reference strains of $S$. aureus.

\begin{tabular}{|c|c|c|c|c|c|}
\hline \multirow{2}{*}{ Peptide } & \multirow{2}{*}{$\begin{array}{l}\mathrm{MHC}^{1} \\
(\mu \mathrm{g} / \mathrm{mL})\end{array}$} & \multirow{2}{*}{$\begin{array}{c}\mathrm{IC}_{50} \\
(\mu \mathrm{g} / \mathrm{mL})\end{array}$} & \multirow{2}{*}{$\begin{array}{c}\mathrm{GM}^{2} \\
(\mu \mathrm{g} / \mathrm{mL})\end{array}$} & \multicolumn{2}{|c|}{ Selectivity Index (SI) ${ }^{3}$} \\
\hline & & & & MHC/GM & $\mathrm{IC}_{50} / \mathrm{GM}$ \\
\hline I & $>256.00$ & 84.20 & $>256.00$ & NA & NA \\
\hline II & $>256.00$ & 38.73 & 73.52 & NA & 0.53 \\
\hline III & 256.00 & 10.13 & 9.19 & 27.86 & 1.10 \\
\hline IV & 64.00 & 3.23 & 2.30 & 27.83 & 1.41 \\
\hline V & 4.00 & 5.97 & 4.00 & 1.00 & 1.49 \\
\hline VI & 4.00 & 7.60 & 27.86 & 0.14 & 0.27 \\
\hline VII & 4.00 & 1.29 & 64.00 & 0.06 & 0.02 \\
\hline VIII & $>256.00$ & 40.50 & 18.38 & NA & 2.20 \\
\hline IX & 32.00 & 10.00 & 4.00 & 8.00 & 2.50 \\
\hline$X$ & $>256.00$ & 74.60 & $>256.00$ & NA & NA \\
\hline
\end{tabular}

${ }^{1} \mathrm{MHC}$ is the minimal hemolytic concentration that caused $5 \%$ hemolysis of human red blood cells. ${ }^{2}$ The geometric

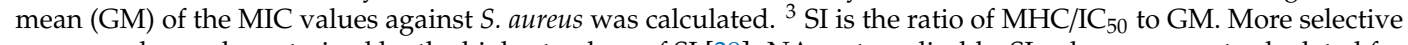
compounds are characterized by the highest values of SI [39]. NA: not applicable; SI values were not calculated for compounds with MHC and/or GM values higher than $256 \mu \mathrm{g} / \mathrm{mL}$.

Peptide net charge and hydrophobicity can affect biological activity, including antimicrobial potency and cytotoxicity as well as also selectivity. Data in Tables 1 and 5 were used to find a relationship between selectivity and hydrophobicity of $\mathrm{KR} 12-\mathrm{NH}_{2}$ analogs (Figures 4 and 5). As seen, longer acyl chain and higher hydrophobicity influenced hemolytic activity to a greater extent than antimicrobial activity, resulting in reduced selectivity indices MHC/GM (Figure 4). Similar tendency was observed in case of selectivity indices $\mathrm{IC}_{50} / \mathrm{GM}$; however, the differences between the peptides are not so spectacular (Figure 5). Interestingly, $\mathrm{KR} 12-\mathrm{NH}_{2}$ modified with aromatic acids (analogs VIII and IX) had highest selectivity indicies $\left(\mathrm{IC}_{50} / \mathrm{GM}\right)$. It has been shown that conjugation of the $N$-terminal amino group of the cationic peptide (Orn-Orn-Trp-Trp- $\mathrm{NH}_{2}$ ) with cinnamic acid (and its derivatives) lead to compounds with promising antimicrobial activity against Gram-positive bacteria (S. aureus) and low cytotoxicity (HaCaT cell line) and hemolytic activity [40]. 


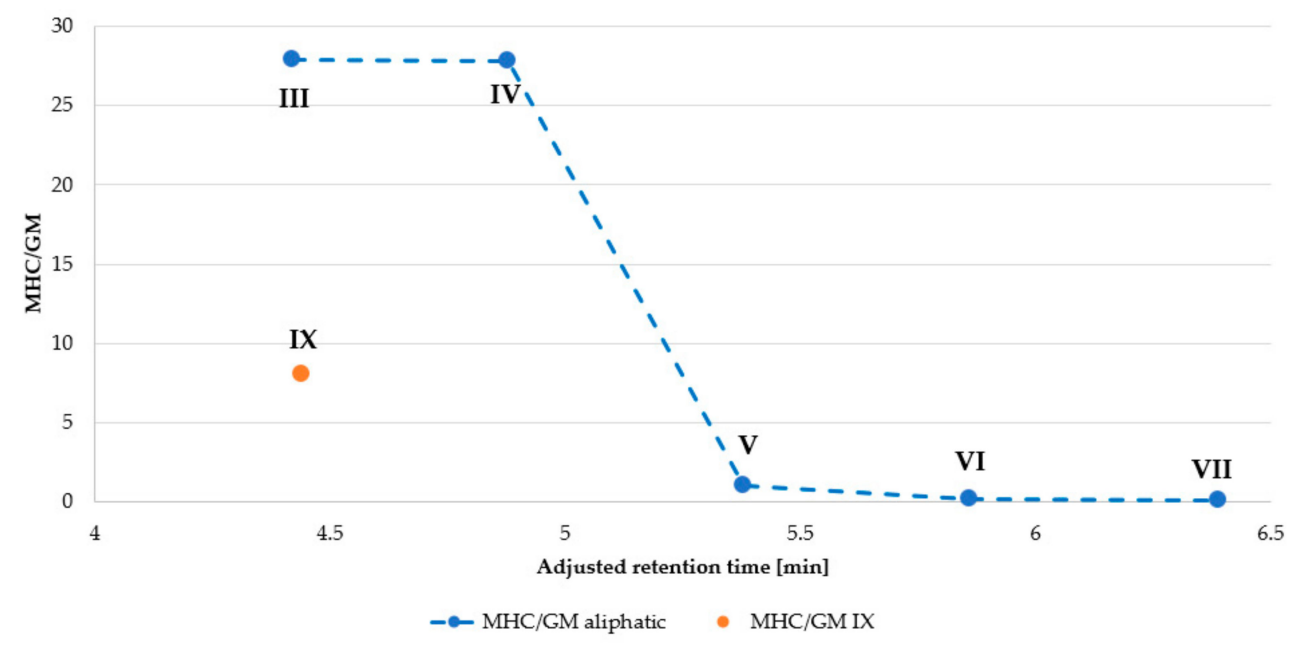

Figure 4. Selectivity for S. aureus over erythrocytes versus adjusted retention time.

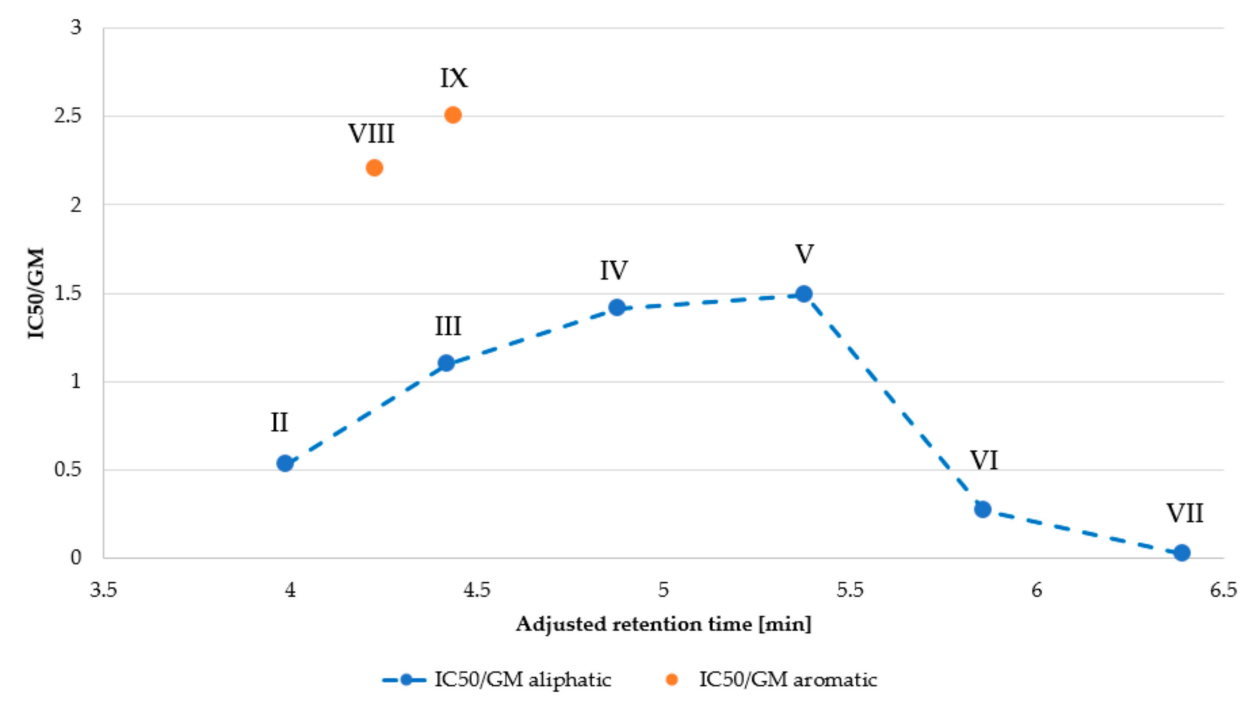

Figure 5. Selectivity for S. aureus over human cells (HaCaT) versus adjusted retention time.

\subsection{Conformational Studies}

The CD spectra (Figure 6) revealed the peptides to be generally devoid of a stable conformation in water and phosphate buffered saline (PBS) solutions, and only addition of membrane-mimicking surfactants such as sodium dodecyl sulfate (SDS) and dodecylphosphocholine (DPC) as well as liposomes such as 1-palmitoyl-2-oleoyl-sn-glycero-3-phosphocholine (POPC) and 1-palmitoyl-2-oleoyl-sn-glycero-3-phosphoglycerol (POPG) induced an $\alpha$-helical structure, but lipopeptides $\mathrm{C}_{10}-\mathrm{KR} 12-\mathrm{NH}_{2}(\mathbf{V}), \mathrm{C}_{12}-\mathrm{KR} 12-\mathrm{NH}_{2}$ (VI) and $\mathrm{C}_{14}-\mathrm{KR} 12-\mathrm{NH}_{2}$ (VII) clearly deviated from this trend. As seen, the CD spectra of compounds V, VI and VII in PBS, as well as of analog VII in water, displayed typical features of peptides with an $\alpha$-helix folding with two well-defined minimums at 208 and $222 \mathrm{~nm}$. A straightforward explanation of this fact is a self-assembly of the lipopeptides, which seems to be a sufficient factor to provide hydrophobic environment stabilizing the helical conformation. In the case of $\mathrm{C}_{14}-\mathrm{KR} 12-\mathrm{NH}_{2}$ (VII), hydrophobic interactions between the tetradecanoic acyl chains were sufficient to overcome the electrostatic and steric repulsion between the peptide residues in both non-buffered and buffered aqueous solutions. In turn, with $\mathrm{C}_{10}-\mathrm{KR} 12-\mathrm{NH}_{2}(\mathbf{V})$ and $\mathrm{C}_{12}-\mathrm{KR} 12-\mathrm{NH}_{2}(\mathrm{VI})$, only an increase in the solution ionic strength resulted in an effective screening of the electrostatic peptide repulsion leading to peptide's self-assembly. Interestingly, a $\Theta 222 / \Theta 208$ ratio greater than 1 noticed in PBS indicated a coiled-coil formation and was a further proof for self-assembly. A similar tendency has previously been observed for conjugates of magainin with lipophilic acids [41]. 

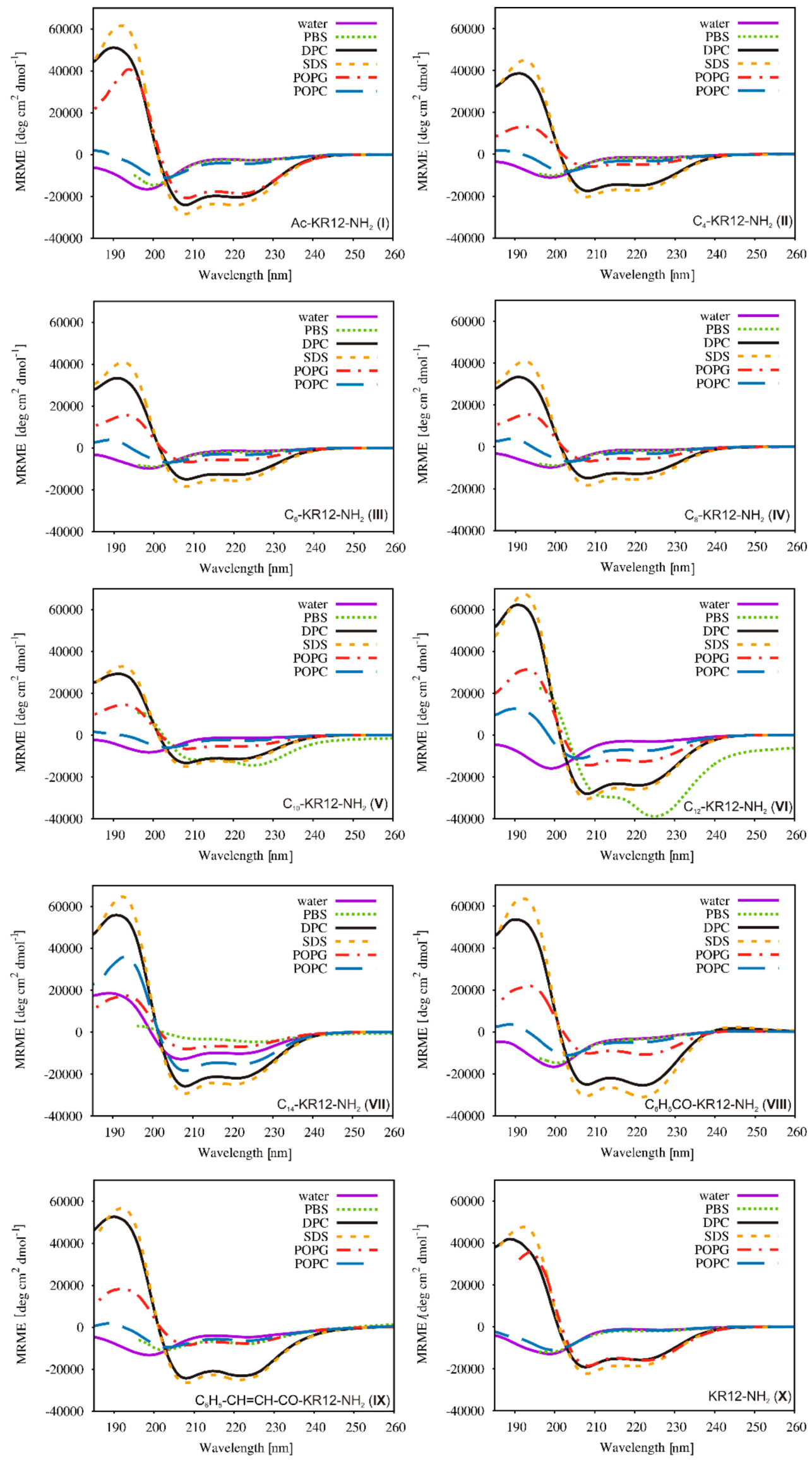

Figure 6. Far-UV CD spectra of the peptides. 
As seen in Figure 6, there were only insignificant differences in the CD spectra of the peptides in SDS and DPC micelles. In both detergents, a high helical content was found for all the peptides studied (45-86\%, Table 6). In turn, POPG and POPC liposomes had a different effect on conformation of the peptides. In general, the presence of POPC liposomes, a model of eukaryotic membranes, induced an increase in helicity with elongation of the attached acyl chain, which correlated well with a rise in hemolytic activity. The $\mathrm{C}_{14}-\mathrm{KR} 12-\mathrm{NH}_{2}$ (VII) analog with the highest helical percentage in POPC liposomes exhibited also the highest cytotoxicity against human keratinocytes. On the other hand, analogs Ac-KR12- $\mathrm{NH}_{2}(\mathrm{I})$ and $\mathrm{C}_{8}-\mathrm{KR} 12-\mathrm{NH}_{2}$ (IV) displayed the same helical fraction (16\%) but extremely different cytotoxicity, because the former was found to be the least cytotoxic, whereas the latter one of the most cytotoxic peptides. This indicated no linear correlation between helicity and toxicity of the peptides studied. In turn, the CD spectra in POPG liposomes, representing a negatively charged bacterial membrane, showed that modifications of $\mathrm{KR}_{12}-\mathrm{NH}_{2}$ with acyl chains longer than that of $C_{4}$ as well as aromatic substituents $\left(C_{7}\right.$ and $\left.C_{9}\right)$ reduced the helical fraction, but without any clear correlation with antimicrobial activity. This result was not surprising at all because numerous studies to date have shown different relationships between helicity and antimicrobial activity. In particular, Shai and Oren have demonstrated that reducing helicity by incorporating D-amino acids decreased hemolytic activity but did not affect most of the potent antimicrobial activity of the diastereomeric analogs as compared to that of the parent peptides [42,43]. Comparable results have been reported for Temporin L analogs [44]. In turn, a study on enantiomers of Pleurocidin [45] has shown all the D-amino acid-containing peptides exhibited a decreased antibacterial activity and a dramatically decreased hemolytic activity as that of compared to L-amino acid-containing counterpart despite a higher percentage of helical structure. All this suggests that conformation of the peptides is not the only factor affecting biological activity.

Table 6. Helical content determined based on CD spectra.

\begin{tabular}{ccccccc}
\hline \multirow{2}{*}{ Peptide } & \multicolumn{7}{c}{ Helical Content \% } \\
\cline { 2 - 7 } & Water & PBS & DPC & SDS & POPG & POPC \\
\hline I & 8 & 8 & 72 & 82 & 69 & 16 \\
II & 7 & 6 & 69 & 71 & 67 & 9 \\
III & 7 & 7 & 65 & 67 & 24 & 16 \\
IV & 6 & 6 & 53 & 62 & 27 & 16 \\
V & 6 & 51 & 45 & 54 & 26 & 15 \\
VI & 8 & 74 & 81 & 86 & 55 & 32 \\
VII & 35 & 17 & 77 & 84 & 29 & 63 \\
VIII & 8 & 5 & 73 & 82 & 41 & 15 \\
IX & 7 & 19 & 72 & 77 & 30 & 18 \\
X & 7 & 7 & 66 & 70 & 66 & 7 \\
\hline
\end{tabular}

\subsection{Self-Assembly Studies}

The critical aggregation concentrations (CACs) were determined for the analogs with $N$-terminal fatty acids $\mathrm{C}_{8}-\mathrm{C}_{14}$ (Figure 7). The surface tension measurements were carried out in pure water, because the peptides aggregated in PBS solution. This is probably the consequence of self-assembly at much lower CAC values according to the rule that an increase in ionic strength of the solution decreases the CAC value of ionic surfactants [46-48]. 


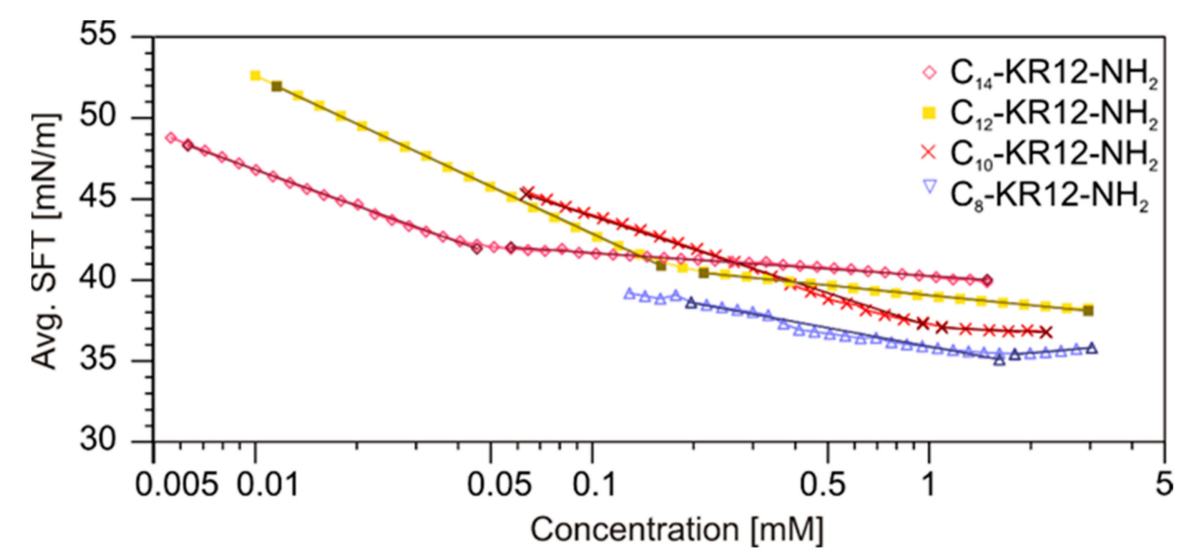

Figure 7. Relationship between the surface tension and peptide concentration.

As expected, the longer was the lipophilic acyl chain, the more effective self-assembly became, owing to an increase in intermolecular hydrophobic interactions. The CAC values decreased with increasing alkyl chain length following the order: $1.46 \mathrm{mM}(2475 \mu \mathrm{g} / \mathrm{mL}), 1.05 \mathrm{mM}(1807 \mu \mathrm{g} / \mathrm{mL})$, $0.17 \mathrm{mM}(297 \mu \mathrm{g} / \mathrm{mL})$ and $0.042 \mathrm{mM}(74 \mu \mathrm{g} / \mathrm{mL})$ for IV, V, VI and VII, respectively. In the ${ }^{1} \mathrm{H}$ NMR spectra, the self-assembly induced broadening of the resonance lines (Figure 8A), which is related to a decrease in system's tumbling rate and shortening of the $\mathrm{T}_{2}$ relaxation times. Interestingly, the NMR spectra of $\mathrm{C}_{8}-\mathrm{KR} 12-\mathrm{NH}_{2}(\mathrm{IV})$ and $\mathrm{C}_{14}-\mathrm{KR} 12-\mathrm{NH}_{2}$ (VII), both recorded at a concentration above CAC, differed from each other despite identical peptide sequences, reflecting different conformations of the peptides. In the latter case, the amide proton resonances were spread out over a wider range of chemical shifts as compared to that of the former, this being characteristic of formation of helical structure [49]. The translation diffusion coefficient $\left(D_{\mathrm{tr}}\right)$ determined at a concentration higher than $\mathrm{CAC}$ of $\mathrm{C}_{14}-\mathrm{KR} 12-\mathrm{NH}_{2}(\mathrm{VII})$ and the corresponding hydrodynamic radius $\left(\mathrm{R}_{\mathrm{H}}\right)$, derived from the Stokes-Einstein's equation were $7.76 \times 10^{-11} \mathrm{~m}^{2} / \mathrm{s}$ and $32 \AA$, respectively. Due to the low CAC value, it was difficult to measure the self-diffusion coefficient for the monomer of peptide VII. Hence, the length of a single molecule was established to be $\sim 35 \AA$ assuming a tetradecanoic acyl tail and the peptide moiety to exist in full-extended and helical conformations, respectively. This value corresponded well with $\mathrm{R}_{\mathrm{H}}$ extracted from the translation diffusion coefficient. Therefore, we concluded that $\mathrm{C}_{14}-\mathrm{KR} 12-\mathrm{NH}_{2}$ self-assembled into micelles. In the case of $\mathrm{C}_{8}-\mathrm{KR} 12-\mathrm{NH}_{2}(\mathrm{IV})$, the translation diffusion coefficients, $D_{\mathrm{tr}}$, extracted from the NMR experiments at concentrations three-fold lower and three-fold higher than CAC were $1.95 \times 10^{-10}$ and $1.74 \times 10^{-10} \mathrm{~m}^{2} / \mathrm{s}$, respectively, and corresponded to the $D_{\mathrm{tr}}$, oligomer $/ D_{\mathrm{tr}}$, monomer ratio of roughly 0.89 . Based on the previous study, the $D_{\mathrm{tr} \text {, oligomer }} / \mathrm{D}_{\mathrm{tr}}$ monomer ratio of $\sim 0.8$ is related to dimer formation by assuming that both the monomer, and the dimer adopt compact (spherical) structures. With the peptides of elongated shapes, this ratio may increase $[50,51]$. For comparison, in the case of common surfactants, SDS and 1,2-diheptanoyl-sn-grycero-3-phosphocholine (DHPC), as well as other antimicrobial lipopeptides, which self-assemble into spherical micelles, the $D_{\mathrm{tr}}$, micelle $/ D_{\mathrm{tr}}$, monomer ratio is lower than 0.5 [52-54]. Taking all this into account, we speculate that $\mathrm{C}_{8}-\mathrm{KR} 12-\mathrm{NH}_{2}$ self-assembled into dimers and the oligomerization over the tested concentration range does not favor helix formation. 

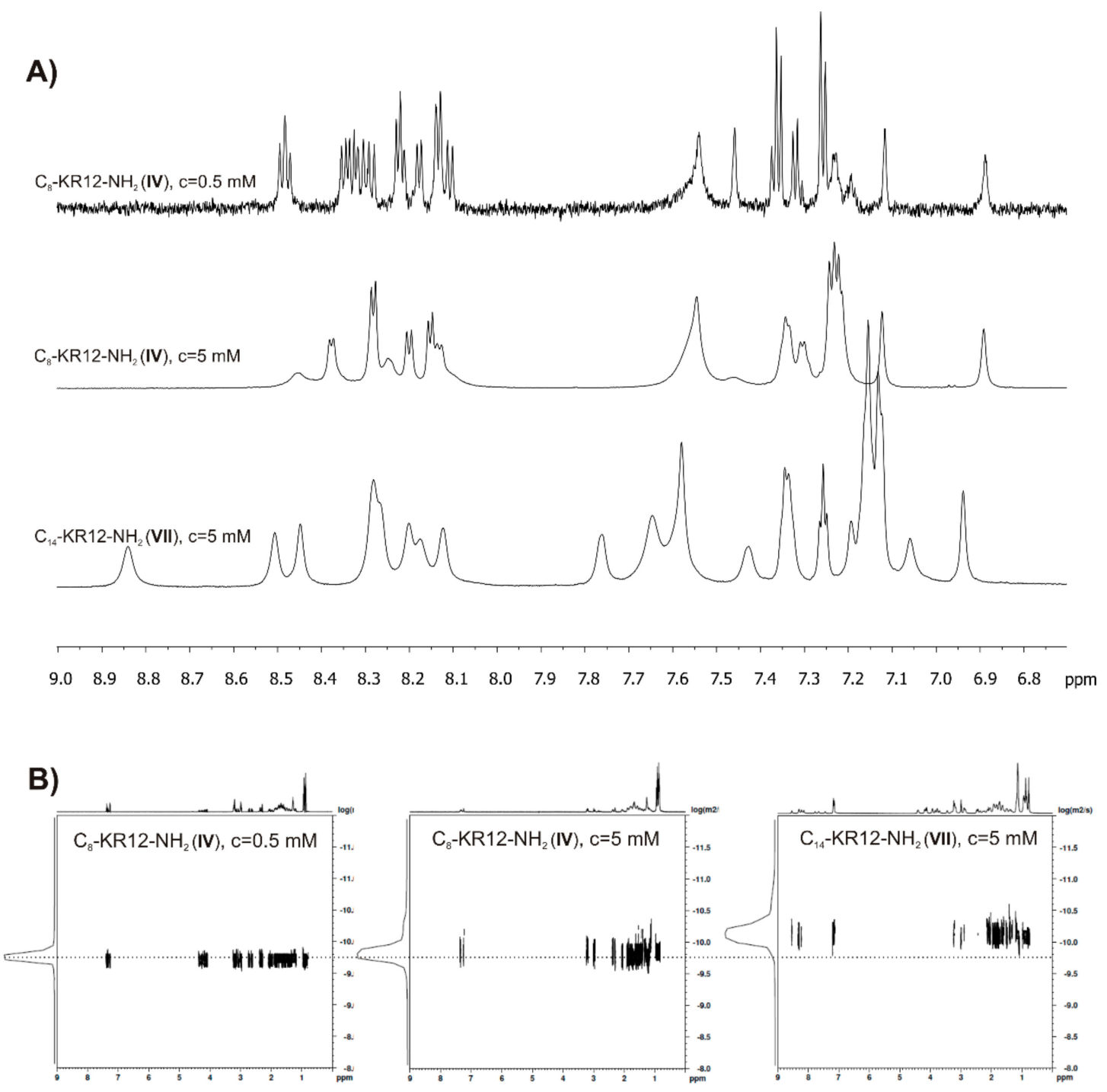

Figure 8. ${ }^{1} \mathrm{H}$ NMR (A) and DOSY (B) spectra for $\mathrm{C}_{8}-\mathrm{KR} 12-\mathrm{NH}_{2}$ and $\mathrm{C}_{14}-\mathrm{KR} 12-\mathrm{NH}_{2}$ recorded at concentrations below and/or above critical aggregation concentration (CAC).

\section{Materials and Methods}

\subsection{Peptide Synthesis}

The peptides (Table 1) were synthesized by solid-phase method using Fmoc chemistry on a resin modified by a Rink amide linker with a loading of $1.0 \mathrm{mmol} / \mathrm{g}$ (Orpegen Peptide Chemicals GmbH, Heidelberg, Germany) [55,56]. $N^{\alpha}$-Fmoc-protected amino acids and the coupling reagents were obtained from Iris Biotech $\mathrm{GmbH}$ (Marktredwitz, Germany). The following amino acids side-chain-protecting groups were used: Trt (for Gln), OtBu (Asp), Boc (Lys), Pbf (Arg). Peptide synthesis was carried out manually. Single deprotection of the Fmoc group was performed in a $20 \%(v / v)$ piperidine (Iris Biotech $\mathrm{GmbH}$, Marktredwitz, Germany) solution in N,N-dimethylformamide (DMF) for $15 \mathrm{~min}$. Acylation with a protected amino acid was conducted in a dichloromethane (DCM)/DMF (Merck, Poland) solution with coupling agents for $1.5 \mathrm{~h}$ using a 3-fold molar excess of $N, N^{\prime}$-diisopropylcarbodiimide (DIC; Peptideweb, Zblewo, Poland) and OxymaPure (Iris Biotech $\mathrm{GmbH}$, Marktredwitz, Germany). Every step was preceded by rinsing the resin and running the chloranil test. Coupling reactions of lipophilic residues (fatty acids, aromatic acids) were performed by the same method as that used for protected amino acids. After the synthesis, the peptide resins were 
dried under vacuum. The peptides were cleaved from the resin using a mixture of trifluoroacetic acid (TFA; Apollo Scientific, Denton, UK), triisopropylsilane (TIS; Sigma-Aldrich, St. Louise, MO, USA), and water (95:2.5:2.5 $v / v / v)$. The cleaved peptides were precipitated with cold diethyl ether and lyophilized. All peptides were purified using the RP-HPLC on a Knauer system controlled by an LPchrom data system (Lipopharm.pl, Zblewo, Poland) with a Knauer Kromasil C 8 column $(8 \times 250$ mm, $100 \AA$ pore size, $5 \mu \mathrm{m}$ particle size). The eluates were fractionated and analyzed by analytical RP-HPLC. The purity of the peptides was determined on a Varian ProStar HPLC system controlled by a Galaxie Chromatography Data System with Phenomenex Gemini-NX C18 column $(4.6 \times 150 \mathrm{~mm}, 110 \AA$ A pore size, $5 \mu \mathrm{m}$ particle size). The solvent systems used were: $0.1 \%$ aqueous TFA (A) and $0.1 \%$ TFA in acetonitrile (ACN) (B). UV detection at $214 \mathrm{~nm}$ was used, and the peptides were eluted with a linear gradient $10-100 \% \mathrm{~B}$ in A over $10 \mathrm{~min}$ at $25 \pm 0.1{ }^{\circ} \mathrm{C}$. The mobile phase flow rate was $2.0 \mathrm{~mL} / \mathrm{min}$. The ESI MS (Waters Alliance e2695 system with Acquity QDA detector, Waters, Milford, MA, USA) was used to identify the masses of the obtained peptides.

\subsection{Antimicrobial Assays}

\subsubsection{Microbial Strains and Antimicrobial Assay}

Examination of antimicrobial activity of the test compounds was conducted on reference strains of bacteria assigned to ESKAPE group of pathogens: Enterococcus faecium ATCC 700221, Klebsiella pneumoniae ATCC 700603, Acinetobacter baumannii ATCC BAA-1605, Pseudomonas aeruginosa ATCC 9027, Klebsiella aerogenes ATCC 13048 (formerly Enterobacter aerogenes) and reference strains of Staphylococcus aureus, namely: S. aureus ATCC 25923, S. aureus ATCC 6538, S. aureus ATCC 33591 (MRSA), S. aureus ATCC 9144 and S. aureus ATCC 12598. All the strains were stored at $-80^{\circ} \mathrm{C}$ in Roti ${ }^{\circledR}$-Store cryo vials (Carl Roth $\mathrm{GmbH}$, Karlsruhe, Germany) and before the tests were transferred into fresh Mueller-Hinton Medium (BioMaxima, Lublin, Poland) and incubated for $24 \mathrm{~h}$ at $37^{\circ} \mathrm{C}$. Subsequently, each bacterial inoculum was seeded on Mueller-Hinton Agar plates (BioMaxima) and incubated again for $24 \mathrm{~h}$. The cultures prepared in this way were used in further antimicrobial assays and prepared as described above. The MIC values were determined by the broth microdilution method according to Clinical and Laboratory Standards Institute Protocol [57]. For this purpose, initial inoculums of bacteria $\left(0.5 \times 10^{5}\right.$ colony forming unit $\left.(\mathrm{CFU}) / \mathrm{mL}\right)$ in Mueller-Hinton Broth were exposed to the ranging concentrations of compounds $(0.5-256 \mu \mathrm{g} / \mathrm{mL})$ and incubated for $18 \mathrm{~h}$ at $37^{\circ} \mathrm{C}$. The experiments were conducted on 96-well microtiter plates, with a final volume of $100 \mu \mathrm{L}$. Cell densities were adjusted spectrophotometrically (Multiskan ${ }^{\mathrm{TM}}$ GO Microplate Spectrophotometer, Thermo Scientific) at $600 \mathrm{~nm}$. The MICs were taken as the lowest drug concentration at which a visible growth of microorganisms was inhibited [58]. All experiments were conducted in triplicate and included positive (growth) and negative (sterility) controls.

\subsubsection{Activity Against Staphylococcal Biofilm}

The MBECs values were determined according to the method reported previously $[59,60]$. Briefly, 24-h cultures of S. aureus, namely: S. aureus ATCC 25923, S. aureus ATCC 6538, S. aureus ATCC 33591 (MRSA), S. aureus ATCC 9144 and S. aureus ATCC 12598 were diluted to a concentration of $0.5 \times 10^{7} \mathrm{CFU} / \mathrm{mL}$ and added to the test wells of polystyrene microdilution flat-bottom plates. After 24-h of incubation at $37^{\circ} \mathrm{C}$, the wells were rinsed three times with PBS to remove non-adherent cells. Subsequently, $100 \mu \mathrm{L}$ of the test compounds over a concentration range $0.5-256 \mu \mathrm{g} / \mathrm{mL}$ were added to each well and incubated again for $24 \mathrm{~h}$ at $37^{\circ} \mathrm{C}$. After this period, $20 \mu \mathrm{L}$ of the resazurin (7-hydroxy-3H-phenoxazin-3-one-10-oxide, $4 \mathrm{mg} / \mathrm{mL}$ ) solution was added to each well. After $1 \mathrm{~h}$ of incubation, the MBECs were read out. The determined values were recorded as the lowest concentration at which the reduction of resazurin (from blue to pink) was lower or equal to $10 \pm 0.5 \%$ as compared to the positive $(100 \%)$ and negative $(0 \%)$ controls. All experiments were performed in triplicate. 


\subsection{The Hemolysis Assay}

The assay was conducted according to the procedure described previously by Avrahami and Shai [28]. Briefly, the fresh human RBCs with ethylenediaminetetraacetic acid (EDTA) as anticoagulant were rinsed three times with PBS by centrifugation at $800 \times g$ for $10 \mathrm{~min}$ and resuspended in PBS. Serial dilution of peptides $(0.5-256 \mu \mathrm{g} / \mathrm{mL})$ was conducted in PBS on 96-well plates. Then the stock RBCs solution was added up to a final volume of $100 \mu \mathrm{L}$ with a $4 \%$ concentration of erythrocytes $(\mathrm{v} / \mathrm{v})$. The control wells for 0 and $100 \%$ hemolysis were also prepared. They consisted of RBCs suspended in PBS and 1\% of Triton-X 100, respectively. Then, the plates were incubated for $60 \mathrm{~min}$ at $37^{\circ} \mathrm{C}$ and centrifuged at $800 \times g$ for $10 \mathrm{~min}$ at $4{ }^{\circ} \mathrm{C}$ (Sorvall ST 16R Centrifuge, Thermo Scientific). After centrifugation, the supernatant was carefully transferred to new microtiter plates and the release of hemoglobin was monitored by measurement of absorbance at $540 \mathrm{~nm}$ (Multiskan ${ }^{\mathrm{TM}}$ GO Microplate Spectrophotometer). Percentage of hemolysis was calculated based on wells with $100 \%$ hemolysis.

\subsection{MTT Assay}

The cytotoxicity of test compounds $\left(\mathrm{IC}_{50}\right)$ was evaluated for human keratinocytes (HaCaT, ATCC) using classic MTT assay on 96-well plates [61]. In this assay, a colorimetric determination of the cell metabolic activity was carried out. Specifically, the color intensity reflects the number of live cells that can be measured spectrophotometrically. Briefly, the cell line was cultured in a Dulbecco's modified Eagle Medium (Sigma-Aldrich) supplemented with 10\% fetal bovine serum (v/v), 100 units $/ \mathrm{mL}$ of penicillin, $100 \mu \mathrm{g} / \mathrm{mL}$ of streptomycin, and $2 \mathrm{mM} \mathrm{L}$-glutamine and was kept at $37^{\circ} \mathrm{C}$ in a humidified $5 \% \mathrm{CO}_{2}$ incubator. A day after plating 500 cells per well, a series of concentrations $(0.5-500 \mu \mathrm{g} / \mathrm{mL})$ of the test compounds were added. Dimethyl sulfoxide (DMSO) was used as a control in cells at a final concentration of $1.0 \%(v / v)$, which was related to the maximal concentration of the solvent compounds used in the experiment. After $24 \mathrm{~h}$ of incubation with test compounds, a medium containing $1 \mathrm{mg} / \mathrm{mL}$ of MTT was added up to a final concentration of $0.5 \mathrm{mg} / \mathrm{mL}$ and subsequently incubated at $37^{\circ} \mathrm{C}$ for $4 \mathrm{~h}$. Then, the medium was aspirated and the formazan product was solubilized with DMSO. The background absorbance at $630 \mathrm{~nm}$ was subtracted from that at $570 \mathrm{~nm}$ for each well (Epoch, BioTek Instruments, Winooski, VT, USA). Six replicates were conducted for each concentration. All experiments were repeated at least twice and the resulting $\mathrm{IC}_{50}$ values were calculated with a GraFit 7 software (v. 7.0, Erithacus, Berkley, CA, USA).

\section{5. $C D$ Measurements}

Circular dichroism studies were performed in water, $10 \mathrm{mM}$ PBS buffer (pH 7.4), $20 \mathrm{mM}$ SDS micelles, $20 \mathrm{mM}$ DPC micelles, and $1.3 \mathrm{mM}$ LUVs POPG and POPC liposomes. Large unilamellar vesicles (LUVs) were prepared according to the previously described procedure [62]. The CD spectra were recorded on a JASCO J-815 spectropolarimeter at $25^{\circ} \mathrm{C}$ in the $185-260 \mathrm{~nm}$ range. The peptide concentration was $0.15 \mathrm{mg} / \mathrm{mL}$. Every spectrum was scanned three times to amplify the signal-to-noise ratio. The spectra were plotted as a function of the mean residue molar ellipticity (MRME, degree $\mathrm{cm}^{2} \mathrm{dmol}^{-1}$ ) vs. wavelength $(\mathrm{nm})$. Deconvolution of the CD spectra were carried out using CDPro software with CONTINILL algorithm and SMP56 database set [63].

\subsection{Surface Tension Measurements}

Surface tension measurements were performed to determine CAC of selected lipidated $\mathrm{KR} 12-\mathrm{NH}_{2}$ analogs. The measurements were carried out using a Wilhelmy plate method on a K100 tensiometer equipped with two micro-dispensers (Krüss GmbH, Hamburg, Germany). The average value of the surface tension for every concentration was obtained on the basis of 10 measurements. The standard deviations did not exceed $0.1 \mathrm{mN} / \mathrm{m}$. The CAC was determined by plotting the surface tension against the logarithm of compound concentration and was found as the intersection of two lines that best fit through the pre- and post-CAC data. 


\subsection{NMR Measurements}

The NMR spectra were acquired on a Bruker Avance III $700 \mathrm{MHz}$ spectrometer running Topspin 3.2 software in $\mathrm{D}_{2} \mathrm{O}$ and $\mathrm{H}_{2} \mathrm{O}: \mathrm{D}_{2} \mathrm{O}(9: 1 \mathrm{v} / \mathrm{v})$ solution at $298 \mathrm{~K}$. The ${ }^{1} \mathrm{H}$ NMR spectra with excitation sculpting water suppression were recorded with $16 \mathrm{k}$ data points in $\mathrm{F} 2$ dimension. The translation diffusion coefficients $\left(D_{\mathrm{tr}}\right)$ were measured by the standard Bruker pulse program (stebpgp1s19) with WATERGATE solvent suppression, $4 \mathrm{k}$ data points in the $\mathrm{F} 2$ dimension, 32 data points (gradient strengths) in the F1 dimension and with $2 \mathrm{~s}$ relaxation delay. The diffusion time $(\Delta)$ and the maximum duration of gradient distance $(\delta)$ were $200 \mathrm{~ms}$ and $4 \mathrm{~ms}$ in all experiments, respectively. The spectra were processed and analyzed using Topspin 3.2 (BrukerBiospins, Rheinstetten, Germany)).

\section{Conclusions}

The modification of KR12 amide $(\mathbf{X})$ with a lipophilic residue in the $N$-terminal part of the molecule has been found to be an effective way to fortify its antimicrobial activity. For each of the synthesized lipopeptides, the activity against $S$. aureus as well as against bacteria of the ESKAPE group depended on the number of carbon atoms in the substituent. For example, the analog of $\mathrm{KR} 12-\mathrm{NH}_{2}$ (IV) containing octanoic acid residue $\left(\mathrm{C}_{8}\right)$ exhibited the highest potency against all organisms tested in planktonic form (MIC 1-4 $\mu \mathrm{g} / \mathrm{mL}$ ). Moreover, it was able to eradicate biofilms of $S$. aureus strains at relatively low concentrations (MBEC 4-16 $\mu \mathrm{g} / \mathrm{mL}$ ). Furthermore, this peptide was characterized by low toxicity against hRBCs (MHC $64 \mu \mathrm{g} / \mathrm{mL}$ ). For HaCaT, the $\mathrm{IC}_{50}$ value was $3.23 \mu \mathrm{g} / \mathrm{mL}$, but the highest SI values were found for peptides III and IV (MHC/GM amounting to almost 28) and peptide IX with $\mathrm{IC}_{50} / \mathrm{GM}$ ratio of 2.50 .

As has previously been argued, fatty acid conjugation enhances the peptide-membrane interactions [64]. On the other hand, it can either induce or enhance ability to self-assemble in solution, which in turn can perturb the water-membrane partition equilibrium by protecting hydrocarbon chains from water phase, thereby reducing the possibility of peptide membrane insertion. However, aggregation can also increase selectivity of membrane-active anticancer and antimicrobial peptides by reducing effective peptide hydrophobicity and thus affinity towards membranes composed of neutral lipids, such as the outer leaflet of healthy eukaryotic cell membranes [65]. In the case of the peptides studied, an increase in the length of the attached alkyl chain enhanced propensity for self-assembly, promoted formation of larger aggregates and decreased antimicrobial activity, but not cytotoxicity of KR12- $\mathrm{NH}_{2}$ analogs. Interestingly, self-assembly induced also $\alpha$-helix formation in analogs with $\mathrm{C}_{10}-\mathrm{C}_{14}$ lipophilic residues. The remaining peptides underwent a conformational switch typical for most antimicrobial peptides only in the presence of surfactants or lipids mimicking membrane environment. No correlation was found between helicity and activity of the peptides, which shows that the antimicrobial activity is the result of many factors. Those affecting activity include conformation, hydrophobicity, hydrophobic moment, charge and its distribution, size of the hydrophobic/hydrophilic domain or aggregation state in solution $[35,65]$. Conjugation of $\mathrm{KR} 12-\mathrm{NH}_{2}$ peptide with lipophilic acids affected all of them to clearly demonstrate the complexity of lipopeptide-membrane interactions with multiple interconnected phenomena contributing in the final activity.

Analog $\mathrm{KR} 12-\mathrm{NH}_{2}$ (IV), containing octanoic acid, has a strong potential to eliminate both planktonic cells of ESKAPE pathogens and the staphylococcal biofilm, as demonstrated in this study. After characterizing its proteolytic stability, this compound might be a useful peptide template for developing novel antimicrobial agents. We do not exclude the possibility of changes in the peptide sequence, because both LL-37 and its fragments can be degraded by proteases [66]. The literature describes LL-37 derivatives that displayed antistaphylococcal activity in vitro but also maintained their activity in the presence of physiological salts and human serum (analogs FK-13-a1 and FK-13-a7) and were active in vivo and/or ex vivo (17BIPHE2, SAAP-148) [22,24,67,68]. A supplementary examination of improvement of peptide IV selectivity index and its ability to prevent the biofilm formation should also be considered. In addition, the promising antimicrobial activity and low toxicity of peptide IX 
modified with trans-cinnamic acid residue is noteworthy, supporting further studies on improving selectivity index and potential application in staphylococcal infections.

Importantly, lipopeptides are already used in the therapy of bacterial infections. Daptomycin is applied in the treatment of systemic bacterial infections. Moreover, polymyxin B is administered parenterally in patients with bacteremia and urinary-tract infections. Unfortunately, the major disadvantage of polymyxin B treatment is its relatively high nephrotoxicity and neurotoxicity $[69,70]$. On the other hand, daptomycin therapy is associated with dose-dependent myopathy [71]. Lipoglycopeptides are another class of drugs available on the market. Dalbavancin is used in patients with acute bacterial skin and skin structure infections (ABSSSI). This drug is considered to be safe and well-tolerated in the treatment of ABSSSI [72]. Telavancin is another FDA approved lipoglycopeptide for treatment of complicated skin and skin structure infections (cSSSI). Both dalbavancin and telavancin disrupt membrane integrity and cell-wall synthesis [73,74]. Conjugation of a peptide with a fatty acid can increase its stability in serum, tissues and organs. It has been shown that lipidated peptides bind to serum albumin. Moreover, chain length plays pivotal role in peptide stability [41,75-78]. Presumably, conjugation of $\mathrm{KR} 12-\mathrm{NH}_{2}$ with a fatty acid at its $\mathrm{N}$-terminus may lead to increased enzymatic stability. The most active and selective peptides in this study may be useful peptide templates for novel antimicrobial agents. Further studies should estimate peptides proteolytic stability, activity in animal infection models and the influence of the position of the lipophilic moiety within $\mathrm{KR} 12-\mathrm{NH}_{2}$ on both antimicrobial activity and toxicity. As is known from literature, changing the location of the fatty moiety from the $\mathrm{N}$-terminus of the molecule to its $\mathrm{C}$-terminus can lead to a decrease in hemolytic activity of the molecule while not adversely affecting its antibacterial activity [37].

Author Contributions: Conceptualization, E.K., E.S. and W.K.; methodology, E.K., E.S., M.J., M.B. and S.B.; investigation, E.K., E.S., M.J., D.N., M.B., W.B.-R. and S.B.; resources, W.K., E.S. and E.K.; writing-original draft preparation, E.K., E.S, M.J., M.B. and W.K.; writing-review and editing, E.K.; visualization, E.K, E.S., D.N. and M.B.; supervision, E.K.; project administration, E.K. and W.K.; funding acquisition, W.K. All authors have read and agree to the published version of the manuscript.

Funding: This study was supported by a Grant from the Polish National Science Centre (Project No. 2016/23/B/NZ7/02919).

Conflicts of Interest: The authors declare no conflict of interest. The funders had no role in the design of the study; in the collection, analyses or interpretation of data; in the writing of the manuscript, or in the decision to publish the results.

\section{Abbreviations}

$\begin{array}{ll}\text { AMPs } & \text { antimicrobial peptides } \\ \text { Ac } & \text { acetyl group } \\ \text { Boc } & \text { tert-butyloxycarbonyl } \\ \mathrm{C}_{4} & \text { butanoic acid residue } \\ \mathrm{C}_{6} & \text { hexanoic acid residue } \\ \mathrm{C}_{8} & \text { octanoic acid residue } \\ \mathrm{C}_{10} & \text { decanoic acid residue } \\ \mathrm{C}_{12} & \text { dodecanoic acid residue } \\ \mathrm{C}_{14} & \text { tetradecanoic acid residue } \\ \text { CAC } & \text { critical aggregation concentration } \\ \text { CD } & \text { circular dichroism } \\ \text { CFU } & \text { colony forming unit } \\ \text { DCM } & \text { dichloromethane } \\ \text { DHPC } & 1,2 \text {-diheptanoyl-sn-glycero-3-phosphocholine } \\ \text { DIC } & N, N^{\prime} \text {-diisopropylcarbodiimide } \\ \text { DMF } & N, N \text {-dimethylformamide }\end{array}$




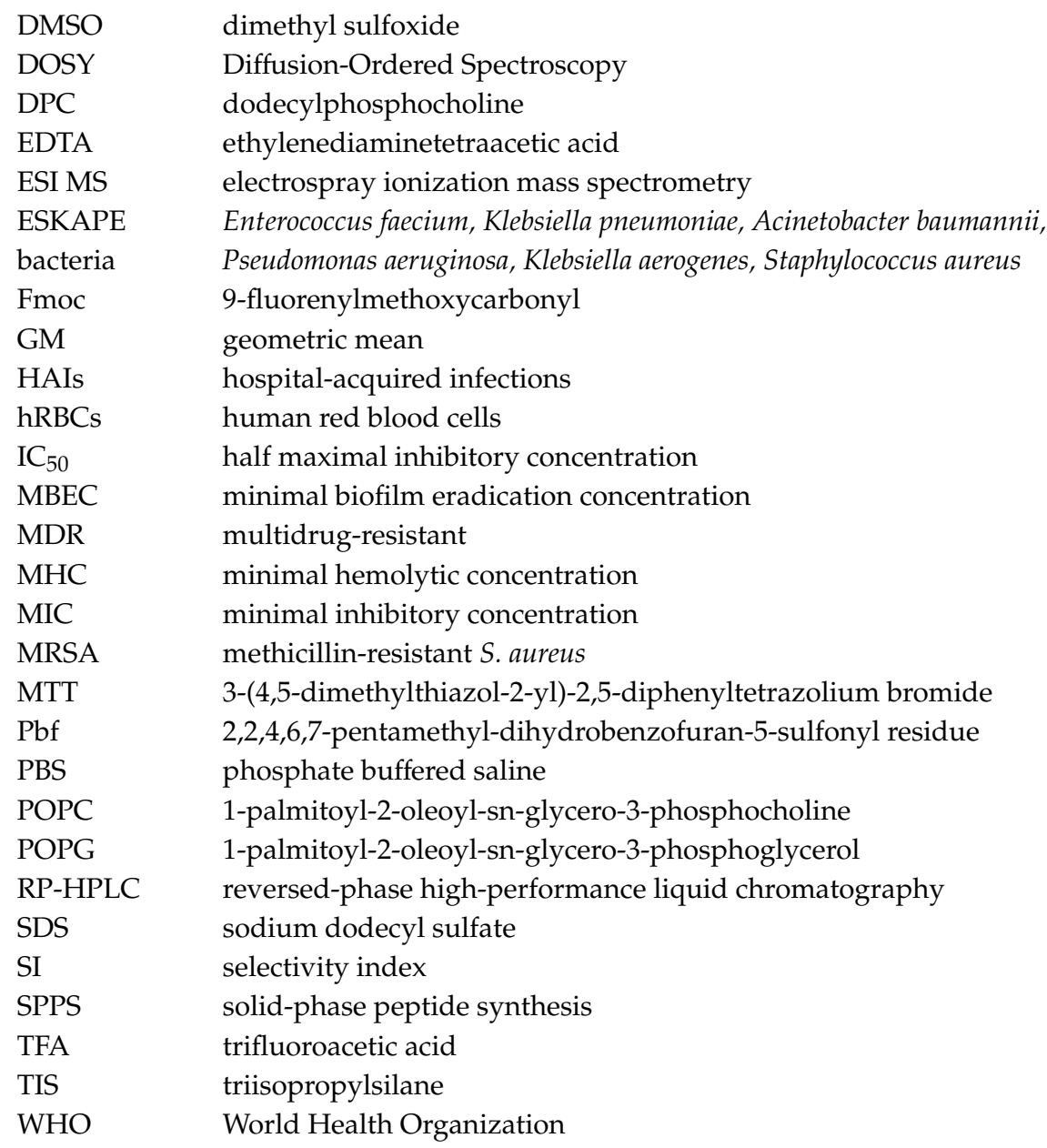

\section{References}

1. Mulani, M.S.; Kamble, E.E.; Kumkar, S.N.; Tawre, M.S.; Pardesi, K.R. Emerging Strategies to Combat ESKAPE Pathogens in the Era of Antimicrobial Resistance: A Review. Front. Microbiol. 2019, 10, 539. [CrossRef]

2. Founou, R.C.; Founou, L.L.; Essack, S.Y. Clinical and economic impact of antibiotic resistance in developing countries: A systematic review and meta-analysis. PLoS ONE 2017, 12, e0189621. [CrossRef] [PubMed]

3. Tacconelli, E.; Carrara, E.; Savoldi, A.; Harbarth, S.; Mendelson, M.; Monnet, D.L.; Pulcini, C.; Kahlmeter, G.; Kluytmans, J.; Carmeli, Y.; et al. Discovery, research, and development of new antibiotics: The WHO priority list of antibiotic-resistant bacteria and tuberculosis. Lancet Infect. Dis. 2018, 18, 318-327. [CrossRef]

4. Messina, G.; Ceriale, E.; Lenzi, D.; Burgassi, S.; Azzolini, E.; Manzi, P. Environmental contaminants in hospital settings and progress in disinfecting techniques. Biomed. Res. Int 2013, 2013, 429780. [CrossRef] [PubMed]

5. Di Ruscio, F.; Guzzetta, G.; Bjørnholt, J.V.; Leegaard, T.M.; Moen, A.E.F.; Merler, S.; Freiesleben de Blasio, B. Quantifying the transmission dynamics of MRSA in the community and healthcare settings in a low-prevalence country. Proc. Natl. Acad. Sci. USA 2019, 116, 14599-14605. [CrossRef]

6. Köck, R.; Becker, K.; Cookson, B.; van Gemert-Pijnen, J.E.; Harbarth, S.; Kluytmans, J.; Mielke, M.; Peters, G.; Skov, R.L.; Struelens, M.J.; et al. Methicillin-resistant Staphylococcus aureus (MRSA): Burden of disease and control challenges in Europe. Eurosurveillance 2010, 15, 19688. [CrossRef]

7. Mah, T.-F. Biofilm-specific antibiotic resistance. Future Microbiol. 2012, 7, 1061-1072. [CrossRef]

8. Sharma, D.; Misba, L.; Khan, A.U. Antibiotics versus biofilm: An emerging battleground in microbial communities. Antimicrob. Resist. Infect. Control 2019, 8, 76. [CrossRef]

9. Haney, E.F.; Hancock, R.E. Peptide design for antimicrobial and immunomodulatory applications. Biopolymers 2013, 100, 572-583. [CrossRef]

10. Hancock, R.E.; Haney, E.F.; Gill, E.E. The immunology of host defence peptides: Beyond antimicrobial activity. Nat. Rev. Immunol. 2016, 16, 321-334. [CrossRef] 
11. Li, W.; Tailhades, J.; O’Brien-Simpson, N.M.; Separovic, F.; Otvos, L., Jr.; Hossain, M.A.; Wade, J.D. Proline-rich antimicrobial peptides: Potential therapeutics against antibiotic-resistant bacteria. Amino Acids 2014, 46, 2287-2294. [CrossRef] [PubMed]

12. Gudmundsson, G.H.; Agerberth, B.; Odeberg, J.; Bergman, T.; Olsson, B.; Salcedo, R. The human gene FALL39 and processing of the cathelin precursor to the antibacterial peptide LL-37 in granulocytes. Eur. J. Biochem. 1996, 238, 325-332. [CrossRef] [PubMed]

13. Dürr, U.H.; Sudheendra, U.S.; Ramamoorthy, A. LL-37, the only human member of the cathelicidin family of antimicrobial peptides. Biochim. Biophys. Acta 2006, 1758, 1408-1425. [CrossRef]

14. Sørensen, O.E.; Follin, P.; Johnsen, A.H.; Calafat, J.; Tjabringa, G.S.; Hiemstra, P.S.; Borregaard, N. Human cathelicidin, hCAP-18, is processed to the antimicrobial peptide LL-37 by extracellular cleavage with proteinase 3. Blood 2001, 97, 3951-3959. [CrossRef]

15. Sørensen, O.E.; Gram, L.; Johnsen, A.H.; Andersson, E.; Bangsbøll, S.; Tjabringa, G.S.; Hiemstra, P.S.; Malm, J.; Egesten, A.; Borregaard, N. Processing of seminal plasma hCAP-18 to ALL-38 by gastricsin: A novel mechanism of generating antimicrobial peptides in vagina. J. Biol. Chem. 2003, 278, 28540-28546. [CrossRef]

16. Cowland, J.B.; Johnsen, A.H.; Borregaard, N. hCAP-18, a cathelin/pro-bactenecin-like protein of human neutrophil specific granules. FEBS Lett. 1995, 368, 173-176. [CrossRef]

17. Burton, M.F.; Steel, P.G. The chemistry and biology of LL37. Nat. Prod. Rep. 2009, 26, 1572-1584. [CrossRef] [PubMed]

18. Noore, J.; Noore, A.; Li, B. Cationic antimicrobial peptide LL-37 is effective against both extra- and intracellular Staphylococcus aureus. Antimicrob. Agents Chemother. 2013, 57, 1283-1290. [CrossRef] [PubMed]

19. Haisma, E.M.; de Breij, A.; Chan, H.; van Dissel, J.T.; Drijfhout, J.W.; Hiemstra, P.S.; El Ghalbzouri, A.; Nibbering, P.H. LL-37-Derived Peptides Eradicate Multidrug-Resistant Staphylococcus aureus from Thermally Wounded Human Skin Equivalents. Antimicrob. Agents Chemother. 2014, 58, 4411-4419. [CrossRef] [PubMed]

20. Saporito, P.; Vang Mouritzen, M.; Løbner-Olesen, A.; Jenssen, H. LL-37 fragments have antimicrobial activity against Staphylococcus epidermidis biofilms and wound healing potential in HaCaT cell line. J. Pept. Sci. 2018, 24, e3080. [CrossRef] [PubMed]

21. Jacob, B.; Park, I.S.; Bang, J.K.; Shin, S.Y. Short KR-12 analogs designed from human cathelicidin LL-37 possessing both antimicrobial and antiendotoxic activities without mammalian cell toxicity. J. Pept. Sci. 2013, 19, 700-707. [CrossRef] [PubMed]

22. Rajasekaran, G.; Kim, E.Y.; Shin, S.Y. LL-37-derived membrane-active FK-13 analogs possessing cell selectivity, anti-biofilm activity and synergy with chloramphenicol and anti-inflammatory activity. Biochim. Biophys. Acta Biomembr. 2017, 1859, 722-733. [CrossRef] [PubMed]

23. Epand, R.F.; Wang, G.; Berno, B.; Epand, R.M. Lipid Segregation Explains Selective Toxicity of a Series of Fragments Derived from the Human Cathelicidin LL-37. Antimicrob. Agents Chemother. 2009, 53, 3705-3714. [CrossRef] [PubMed]

24. Wang, G.; Hanke, M.; Mishra, B.; Lushnikova, T.; Heim, C.E.; Thomas, V.C.; Bayles, K.W.; Kielian, T. Transformation of Human Cathelicidin LL-37 into Selective, Stable, and Potent Antimicrobial Compounds. ACS Chem. Biol. 2014, 9, 1997-2002. [CrossRef]

25. Wang, G. Structures of human host defense cathelicidin LL-37 and its smallest antimicrobial peptide KR-12 in lipid micelles. J. Biol. Chem. 2008, 283, 32637-32643. [CrossRef]

26. Mishra, B.; Epand, R.F.; Epand, R.M.; Wang, G. Structural location determines functional roles of the basic amino acids of KR-12, the smallest antimicrobial peptide from human cathelicidin LL-37. RSC Adv. 2013, 3, 19560-19571. [CrossRef]

27. Li, Z.; Yuan, P.; Xing, M.; He, Z.; Dong, C.; Cao, Y.; Liu, Q. Fatty acid conjugation enhances the activities of antimicrobial peptides. Recent Pat. Food Nutr. Agric. 2013, 5, 52-56. [CrossRef]

28. Avrahami, D.; Shai, Y. A New Group of Antifungal and Antibacterial Lipopeptides Derived from Non-membrane Active Peptides Conjugated to Palmitic Acid. J. Biol. Chem. 2004, 279, 12277-12285. [CrossRef]

29. Albada, B. Tuning Activity of Antimicrobial Peptides by Lipidation. In Health Consequence of Microbial Interactions with Hydrocarbons, Oils, and Lipids, Handbook of Hydrocarbon and Lipid Microbiology; Goldfine, H., Ed.; Springer International Publishing: Cham, Switzerland, 2019; pp. 1-18. 
30. Neubauer, D.; Jaśkiewicz, M.; Bauer, M.; Gołacki, K.; Kamysz, W. Ultrashort Cationic Lipopeptides-Effect of N-Terminal Amino Acid and Fatty Acid Type on Antimicrobial Activity and Hemolysis. Molecules 2020, 25, 257. [CrossRef]

31. Cruz, E.; Euerby, M.R.; Johnson, C.M.; Hackett, C.A. Chromatographic classification of commercially available reverse-phase HPLC columns. Chromatographia 1997, 44, 151-161. [CrossRef]

32. Kimata, K.; Iwaguchi, K.; Onishi, S.; Jinno, K.; Eksteen, R.; Hosoya, K.; Araki, M.; Tanaka, N. Chromatographic characterization of silica c18 packing materials. Correlation between a preparation method and retention behavior of stationary phase. J. Chromatogr. Sci. 1989, 27, 721-728. [CrossRef]

33. Jaśkiewicz, M.; Bauer, M.; Sadowska, K.; Barańska-Rybak, W.; Kamysz, E.; Kamysz, W. Antistaphylococcal activity of the KR-12 alanine scan. In Proceedings of the 35th European Peptide Symposium, Dublin, Ireland, 26-31 August 2018. Poster, Unpublished Work.

34. Dathe, M.; Nikolenko, H.; Meyer, J.; Beyermann, M.; Bienert, M. Optimization of the antimicrobial activity of magainin peptides by modification of charge. FEBS Lett. 2001, 501, 146-150. [CrossRef]

35. Dathe, M.; Wieprecht, T. Structural features of helical antimicrobial peptides: Their potential to modulate activity on model membranes and biological cells. Biochim. Biophys. Acta 1999, 1462, 71-87. [CrossRef]

36. Laverty, G.; McLaughlin, M.; Shaw, C.; Gorman, S.P.; Gilmore, B.F. Antimicrobial activity of short, synthetic cationic lipopeptides. Chem. Biol. Drug Des. 2010, 75, 563-569. [CrossRef] [PubMed]

37. Albada, H.B.; Prochnow, P.; Bobersky, S.; Langklotz, S.; Schriek, P.; Bandow, J.E.; Metzler-Nolte, N. Tuning the activity of a short Arg-Trp antimicrobial peptide by lipidation of a C- or N-terminal lysine side-chain. ACS Med. Chem. Lett. 2012, 3, 980-984. [CrossRef] [PubMed]

38. Kim, E.Y.; Rajasekaran, G.; Shin, S.Y. LL-37-derived short antimicrobial peptide KR-12-a5 and its D-amino acid substituted analogs with cell selectivity, anti-biofilm activity, synergistic effect with conventional antibiotics, and anti-inflammatory activity. Eur. J. Med. Chem. 2017, 136, 428-441. [CrossRef]

39. Lyu, Y.; Yang, Y.; Lyu, X.; Dong, N.; Shana, A. Antimicrobial activity, improved cell selectivity and mode of action of short PMAP-36-derived peptides against bacteria and Candida. Sci. Rep. 2016, 6, 27258. [CrossRef]

40. Laverty, G.; McCloskey, A.P.; Gorman, S.P.; Gilmore, B.F. Anti-biofilm activity of ultrashort cinnamic acid peptide derivatives against medical device-related pathogens. J. Pept. Sci. 2015, 21, 770-778. [CrossRef]

41. Avrahami, D.; Shai, Y. Conjugation of a magainin analogue with lipophilic acids controls hydrophobicity, solution assembly, and cell selectivity. Biochemistry 2002, 41, 2254-2263. [CrossRef]

42. Oren, Z.; Shai, Y. Selective lysis of bacteria but not mammalian cells by diastereomers of melittin: Structurefunction study. Biochemistry 1997, 36, 1826-1835. [CrossRef]

43. Shai, Y.; Oren, Z. Diastereoisomers of cytolysins, a novel class of potent antibacterial peptides. J. Biol. Chem. 1996, 271, 7305-7308. [CrossRef] [PubMed]

44. Mangoni, M.L.; Carotenuto, A.; Auriemma, L.; Saviello, M.R.; Campiglia, P.; Gomez-Monterrey, I.; Malfi, S.; Marcellini, L.; Barra, D.; Novellino, E. Structure-activity relationship, conformational and biological studies of temporin L analogues. J. Med. Chem. 2011, 54, 1298-1307. [CrossRef] [PubMed]

45. Lee, J.; Lee, D.G. Structure-antimicrobial activity relationship between pleurocidin and its enantiomer. Exp. Mol. Med. 2008, 40, 370-376. [CrossRef] [PubMed]

46. Thongngam, M.; McClements, D.J. Influence of $\mathrm{pH}$, ionic strength, and temperature on self-association and interactions of sodium dodecyl sulfate in the absence and presence of chitosan. Langmuir 2005, 21, 79-86. [CrossRef] [PubMed]

47. Manzo, G.; Carboni, M.; Rinaldi, A.C.; Casu, M.; Scorciapino, M.A. Characterization of sodium dodecylsulphate and dodecylphosphocholine mixed micelles through NMR and dynamic light scattering. Magn. Reson. Chem. 2013, 51, 176-183. [CrossRef] [PubMed]

48. Sikorska, E.; Wyrzykowski, D.; Szutkowski, K.; Greber, K.; Lubecka, E.A.; Zhukov, I. Thermodynamics, size, and dynamics of zwitterionic dodecylphosphocholine and anionic sodium dodecyl sulfate mixed micelles. J. Thermal Anal. Calor. 2016, 123, 511-523. [CrossRef]

49. Jeong, J.-H.; Kim, J.-S.; Choi, S.-S.; Kim, Y. NMR structural studies of antimicrobial peptides: LPcin analogs. Biophys. J. 2016, 110, 423-430. [CrossRef]

50. Khakshoor, O.; Demeler, B.; Nowick, J.S. Macrocyclic beta-sheet peptides that mimic protein quaternary structure through intermolecular beta-sheet interactions. J. Am. Chem. Soc. 2007, 129, 5558-5569. [CrossRef]

51. Chang, X.; Keller, D.; O'Donoghue, S.I.; Led, J.J. NMR studies of the aggregation of glucagon-like peptide-1: Formation of a symmetric helical dimer. FEBS Lett. 2002, 515, 165-170. [CrossRef] 
52. Jarvet, J.; Danielsson, J.; Damberg, P.; Oleszczuk, M.; Gräslund, A. Positioning of the Alzheimer Abeta(1-40) peptide in SDS micelles using NMR and paramagnetic probes. J. Biomol. NMR 2007, 39, 63-72. [CrossRef]

53. Chou, J.J.; Baber, J.L.; Bax, A. Characterization of phospholipid mixed micelles by translational diffusion. J. Biomol. NMR 2004, 29, 299-308. [CrossRef] [PubMed]

54. Sikorska, E.; Stachurski, O.; Neubauer, D.; Małuch, I.; Wyrzykowski, D.; Bauer, M.; Brzozowski, K.; Kamysz, W. Short arginine-rich lipopeptides: From self-assembly to antimicrobial activity. Biochim. Biophys. Acta Biomembr. 2018, 1860, 2242-2251. [CrossRef] [PubMed]

55. Chan, W.C.; White, P.D. Fmoc Solid Phase Peptide Synthesis: A Practical Approach; Oxford University Press: New York, NY, USA, 2000; pp. 11-74.

56. Atherton, E.; Sheppard, R.C. Solid Phase Peptide Synthesis: A Practical Approach; IRL Press: Oxford, UK, 1989; pp. 28-38, 75-86, 149-162.

57. Wayne, P.A. Methods for Dilution Antimicrobial Susceptibility Tests for Bacteria That Grow Aerobically; Approved Standard-Ninth Edition; Document M07-A8; Clinical and Laboratory Standards Institute (CLSI): Wayne, PA, USA, 2012; Available online: www.clsi.org (accessed on 20 January 2013).

58. Andrews, J.M. Determination of minimum inhibitory concentrations. J. Antimicrob. Chemother. 2002, 49, 1049. [CrossRef]

59. Maciejewska, M.; Bauer, M.; Neubauer, D.; Kamysz, W.; Dawgul, M. Influence of amphibian antimicrobial peptides and short lipopeptides on bacterial biofilms formed on contact lenses. Materials (Basel) 2016, 9, 873. [CrossRef] [PubMed]

60. Migoń, D.; Jaśkiewicz, M.; Neubauer, D.; Bauer, M.; Sikorska, E.; Kamysz, E.; Kamysz, W. Alanine Scanning Studies of the Antimicrobial Peptide Aurein 1.2. Probiotics Antimicrob. Proteins 2019,11,1042-1054. [CrossRef] [PubMed]

61. Stachurski, O.; Neubauer, D.; Małuch, I.; Wyrzykowski, D.; Bauer, M.; Bartoszewska, S.; Kamysz, W.; Sikorska, E. Effect of self-assembly on antimicrobial activity of double-chain short cationic lipopeptides. Bioorg. Med. Chem. 2019, 27, 115129. [CrossRef]

62. Sikorska, E.; Dawgul, M.; Greber, K.; Iłowska, E.; Pogorzelska, A.; Kamysz, W. Self-assembly and interactions of short antimicrobial cationic lipopeptides with membrane lipids: ITC, FTIR and molecular dynamics studies. BBA-Biomembranes 2014, 1838, 2625-2634. [CrossRef]

63. Sreerama, N.; Woody, R.W. Estimation of Protein Secondary Structure from Circular Dichroism Spectra: Comparison of CONTIN, SELCON, and CDSSTR Methods with an Expanded Reference Set. Anal. Biochem. 2000, 287, 252-260. [CrossRef]

64. Chu-Kung, A.F.; Bozzelli, K.N.; Lockwood, N.A.; Haseman, J.R.; Mayo, K.H.; Tirrell, M.V. Promotion of peptide antimicrobial activity by fatty acid conjugation. Bioconjug. Chem. 2004, 15, 530-535. [CrossRef]

65. Vaezi, Z.; Bortolotti, A.; Luca, V.; Perilli, G.; Mangoni, M.L.; Khosravi-Far, R.; Bobone, S.; Stella, L. Aggregation determines the selectivity of membrane-active anticancer and antimicrobial peptides: The case of killerFLIP. Biochim Biophys Acta Biomembr. 2020, 1862, 183107. [CrossRef]

66. McCrudden, M.T.C.; McLean, D.T.F.; Zhou, M.; Shaw, J.; Linden, G.J.; Irwin, C.H.R.; Lundy, F.T. The Host Defence Peptide LL-37 is Susceptible to ProteolyticDegradation by Wound Fluid Isolated from Foot Ulcersof Diabetic Patients. Int. J. Pept. Res. Ther. 2014, 20, 457-464. [CrossRef]

67. Mishra, B.; Golla, R.M.; Lau, K.; Lushnikova, T.; Wang, G. Anti-Staphylococcal Biofilm Effects of Human Cathelicidin Peptides. ACS Med. Chem. Lett. 2016, 7, 117-121. [CrossRef] [PubMed]

68. Riool, M. Novel Antibacterial Strategies to Combat Biomaterial-Associated Infections. Ph.D. Thesis, University of Amsterdam, Amsterdam, The Netherlands. Available online: https://hdl.handle.net/11245.1/ db3811ec-92ce-4831-b7c7-f1c0bcc76bc9 (accessed on 27 January 2020).

69. Falagas, M.E.; Kasiakou, S.K. Toxicity of polymyxins: A systematic review of the evidence from old and recent studies. Crit Care. 2006, 10, R27. [CrossRef] [PubMed]

70. Pastewski, A.A.; Caruso, P.; Parris, A.R.; Dizon, R.; Kopec, R.; Sharma, S.; Mayer, S.; Ghitan, M.; Chapnick, E.K. Parenteral polymyxin B use in patients with multidrug-resistant gram-negative bacteremia and urinary tract infections: A retrospective case series. Ann. Pharmacother. 2008, 42, 1177-1187. [CrossRef]

71. Steenbergen, J.N.; Alder, J.; Thorne, G.M.; Tally, F.P. Daptomycin, a New Cyclic Lipopeptide Antibiotic, for the Treatment of Resistant Gram-Positive Organisms. J. Antimicrob. Chemother. 2005, 55, 283-288. [CrossRef] 
72. Dunne, M.W.; Talbot, G.H.; Boucher, H.W.; Wilcox, M.; Puttagunta, S. Safety of Dalbavancin in the Treatment of Skin and Skin Structure Infections: A Pooled Analysis of Randomized, Comparative Studies. Drug Saf. 2016, 39, 147-157. [CrossRef]

73. Pushkin, R.; Barriere, S.L.; Wang, W.; Corey, G.R.; Stryjewski, M.E. Telavancin for Acute Bacterial Skin and Skin Structure Infections, a Post Hoc Analysis of the Phase 3 ATLAS Trials in Light of the 2013 FDA Guidance. Antimicrob. Agents Chemother. 2015, 59, 6170-6174. [CrossRef]

74. Roberts, K.D.; Sulaiman, R.M.; Rybak, M.J. Dalbavancin and Oritavancin: An Innovative Approach to the Treatment of Gram-Positive Infections. Pharmacotherapy 2015, 35, 935-948. [CrossRef]

75. Zhang, L.; Bulaj, G. Converting Peptides into Drug Leads by Lipidation. Curr. Med. Chem. 2012, 19, 1602-1618. [CrossRef]

76. Poupart, J.; Hou, X.; Chemtob, S.; Lubell, W.D. Application of N-Dodecyl 1-Peptide to Enhance Serum Stability while Maintaining Inhibitory Effects on Myometrial Contractions Ex Vivo. Molecules 2019, $24,4141$. [CrossRef]

77. Toth, I.; Flinna, N.; Hillery, A.; Gibbons, W.A.; Artursson, P. Lipidic conjugates of luteinizing hormone releasing hormone $(\mathrm{LHRH})+$ and thyrotropin releasing hormone $(\mathrm{TRH})+$ that release and protect the native hormones in homogenates of human intestinal epithelial (Caco-2) cells. Int. J. Pharm. 1994, 105, 241-247. [CrossRef]

78. Zhang, L.; Robertson, C.R.; Green, B.R.; Pruess, T.H.; White, H.S.; Bulaj, G. Structural requirements for a lipoamino acid in modulating the anticonvulsant activities of systemically active galanin analogues. J. Med. Chem. 2009, 52, 1310-1316. [CrossRef] [PubMed]

(C) 2020 by the authors. Licensee MDPI, Basel, Switzerland. This article is an open access article distributed under the terms and conditions of the Creative Commons Attribution (CC BY) license (http://creativecommons.org/licenses/by/4.0/). 